\title{
منهجية الإمام الحصيري في ترتيب الأبواب الفقهية من خلال كتابه الحاوي في الفتاوى -دراسة مقارنة
}

\begin{abstract}
ملمّّص
تتناول هذه الدراسة تقسيمات الأبواب الفقهية عند الإمام الحصيري في كتابه حاوي الفتاوى والمعروف أيضا بحاوي الحصيري، مع مقارنة تقسيم الأبواب الفقهية بمنهجية علماء المذهب الحنفي في تقسيمات الأبواب الفقهية، وبعدها يتم مقارنتها بمنهجية تقسيمات علماء الشافعية لأبواب الفقة، يقسم الإمام الحصيري الأبواب الفقهية إلى أربعة أقسام، القسم

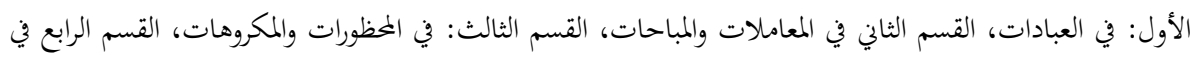
الجنايات والعقوبات، وجعل تحت كل قسم أبواب متعددة، وختم كتابه بخاتمة سماها القسم الأخير تناول فيها موضوعات

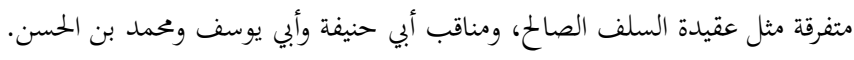
من خلال الدراسة يتم عرض الموضوعات الفقهية التي ذكرها الإمام الحصيري واحدة تلو الأخرى، ومن ثمة نحاول بيان وتوضيح أسباب ورود الأبواب الفقهية في تلك الأقسام وتعلقها، وذكر مناسبة الكتب في ورودها وترتيبها من خلال

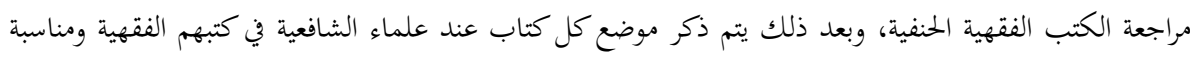
ورودها، ومحاولة تمييز الاختلاف بين تقسيمات الحصيري للأبواب الفقهية وتقسيمات علماء المذهب الحنفي، وكذلك وكن الأمر مع تقسيمات المذهب الشافعي للأبواب الفقهية. تميز ترتيب الإمام الحصيري للموضوعات الفقهية في كتابه حاوي الفتاوى عن نمط ترتيب الأبواب الفقهية عند علماء

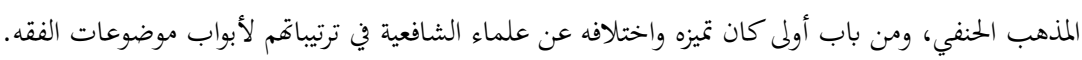
الكلمات المفاتيح: الحصيري، التبويب الفقهي، الحاوي. موضوعات الفقه.
\end{abstract}

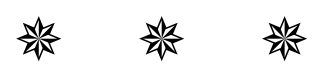

zahra.albakri7@gmail.com دكتور، جامعة ساكاريا، a

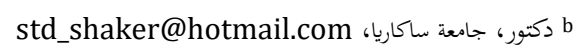




\section{IMMAM EL-HASîRî'NİN (500/1107) EL-HAVÎ FİL-FETÂVÂ ADLI ESERIININ FIKH BABLARININ SISTEMATIĞĠ: KARŞILAŞTIRMALI BİR ÇALIŞMA}

Makelede imam Hasirî'nin Havi'l-Hasirî ismiyle meşhur olan, "el-Havi fi'l-fetâvâ" adlı eserindeki fikıh bablarının taksimi, önce Hanefi mezhebi alimlerinin daha sonra da Şâfii mezhebi alimlerinin kendilerine has sistematileriyle yazılmış fikıh bablarının taksimiyle kıyaslanmıştır. Hasirî eserini dört kısımdan oluşturmaktadır. Bu dört kısım "el-ibadat ve'l-kurubât", "el-muâmelât ve'lmübâhât", "el-mahzûrat ve'l-mekrûhat" ve "el-cinâyât" başlıklarını taşımaktadır.

Bu dört kısmın ardından eser "hâtime" adı verilen kısımla bitirilmektedir. Bu bölümde ehl-i sünnet akidesiyle, fikhın şerefiyle, fetvanın adabıyla; Ebu Hanife, Ebu Yusuf ve İmam Muhammed'in menkıbeleriyle ve en son mezhebini terk edenlere eleştiriyle ilgili konular yer almaktadır.

Makelede Hasirî'nin eserinde zikrettiği fikıh konularını tek tek ele alarak açıklanmış, daha sonra bütün bölümlerdeki fikıh bablarının sistematilerini, nedeni ve bunlarla ilgisinin kapsamını açıklamaya ve netleştirmeye çalışılmıştır. $\mathrm{Bu}$ eserin sistematiğinin keyfiyeti, gerekçeleri ve varsa özgünlüğünü izah edebilmek için diğer hanefi ve şafii mezhebindeki eserlerin sistemiyle mukayese edildiğini de belirtmek yerinde olacaktır. Makelede Hasirî'nin fikıh bablarını taksim metodu ile Hanefi mezhebi alimlerinin metodu arasındaki farklılıklar ortaya konulmuştur. Ve bütün konularda Şafiî̀' mezhebi alimlerinin sistematileriyle kıyaslanarak aralarındaki fark ortaya konulmuştur. İmam Hasirî'nin kitabı olan el-Hâvi fi'l-fetâvâ daki fikıh bablarının tertip edilme üslubu ve sistematiği, Hanefi mezhebi alimlerinin fikhî konulardaki fikıh bablarının sistematiğinden farklılık ve ayrıcalık göstermektedir. Şâfiî mezhebi alimlerinin fıkıh konularındaki babları ile kıyaslandığında Hâsirî̀nin eserinin ilk bablarının oldukça özgün ve şahsına münhasır bir metoda sahip olduğunu söylemek mümkündür.

[Geniş Türkçe Öz, çalışmanın sonunda yer almaktadır.]

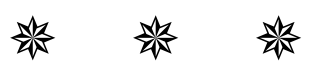

\section{METHODOLOGY OF IMAM AL-HUSAYRI IN STRUCTURING THE FIQH} TOPICS IN HIS BOOK, AL-HAWI FIL FATAWA: A COMPARATIVE STUDY

This study deals with the divisions of the jurisprudential chapters of Imam alHusayri in his book Hawi al-Fatwa, also known as Hawi al-Husayri, and compares them to the division of the jurisprudential chapters with the methodology of the scholars of the Hanafi school of jurisprudential divisions. After that, it is compared with the methodology of the Shafi'i scholars's divisions of the chapters on jurisprudence Imam Al-Husayri divides the chapters on jurisprudence into four sections, The first section: On acts of worship, the second section in transactions and permissible, the third section: On the prohibitions and dislikes, 
the fourth section in the crimes and penalties He made multiple chapters under each section, and concluded his book with a conclusion which he called the last section, in it he dealt with various topics such as the doctrine of the righteous predecessors, the virtues of Abu Hanifa, Abu Yusuf and Muhammad ibn al-Hasan. Through the study, the jurisprudential topics mentioned by Imam Al-Husayri are presented one by one, after that we try to explain and clarify the reasons for the emergence of the jurisprudential chapters in those sections and attach them, also mentioned the reasons for choosing and arranging the books by reviewing the Hanafi jurisprudence books, and after that the position of each book is mentioned when Shafi'i scholars in their books of jurisprudence and the occasion of its introduction, and try to distinguish the difference between the divisions of Al-Husayri of the chapters of jurisprudence and the divisions of scholars of the Hanafi school, as well as the matter with the divisions of the Shafi'i school of chapters of jurisprudence. The order of Imam al-Husayri of jurisprudential topics in his book Hawi al-Fatawa distinguished from the pattern of arranging the chapters of jurisprudence among the scholars of the Hanafi school, And his distinction and difference from the Shafi'i scholars were in their arrangements for the chapters on the topics of jurisprudence.

[The Extended Abstract is the end of article.]

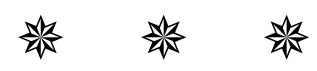

$$
\begin{aligned}
& \text { المقدمة } \\
& \text { تتناول هذه الدراسة تقسيمات الأبواب الفقهية عند الإمام الحصيري لما حواه حاوي الإمام الحصيري من فهرس } \\
& \text { بديع يأسر لب من يلقي نظرة عليه عند الإطلاع على بداية صفحات نسخ مخطوط الحاوي في الفتاوى، وكانت ترتيبات }
\end{aligned}
$$

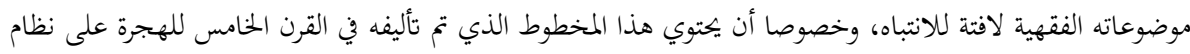

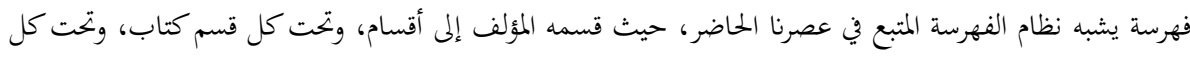

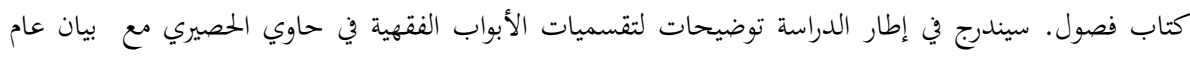

$$
\begin{aligned}
& \text { لتقسيمات المذهب الحنفي لتلك الأبواب، ومحاولة ضبط أسباب إيراد الأبواب والتقسيمات الفقهية بترتيبها الموجود من } \\
& \text { خلال نسخ المخطوطات التي اطلعنا عليها لكتاب حاوي الفتاوى، وبعدها سيتم مقارنة تقسيمات الإمام الحصيري }
\end{aligned}
$$

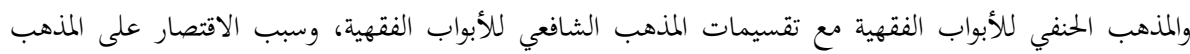

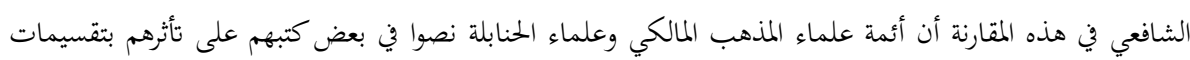

$$
\begin{aligned}
& \text { الشافعية لأبواب الكتب الفقهية. } \\
& \text { والناظر في كتب الفقه الإسلامي ومن خلال الإستقراء لأبواب الكتب الفقهية تلك يلاحظ على سبيل المثال } \\
& \text { في قسم المعاملات، أن المالكية والشافعية والحنابلة يثبتون في كتبهم أن المعاملات لا لا تعني سوى عقود البيوع وما شابهها، }
\end{aligned}
$$

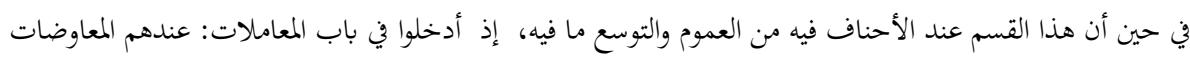


المالية والمناكحات والمخاصمات والأمانات، والتركات 1. وقد نص بعض العلماء السابقيين من المالكية والحنابلة بشكل واضح وصريح على تأثرهم في ترتيب الأبواب

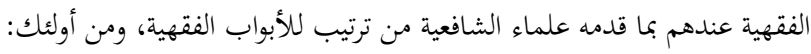

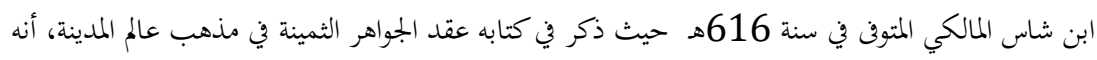

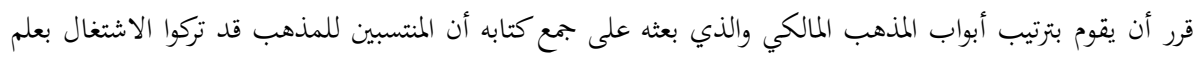

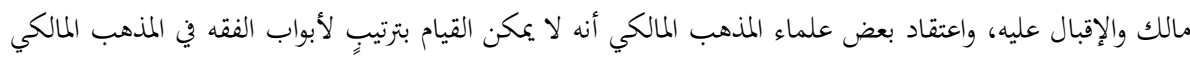

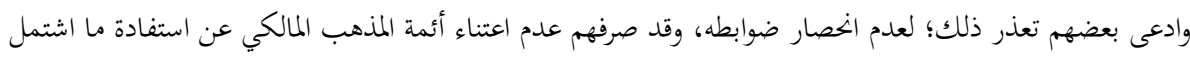

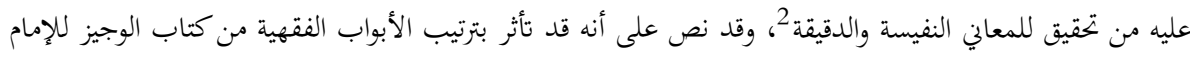

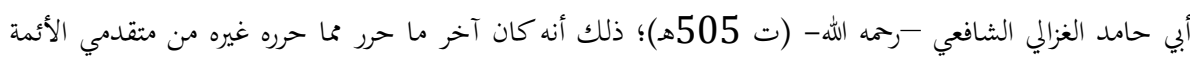

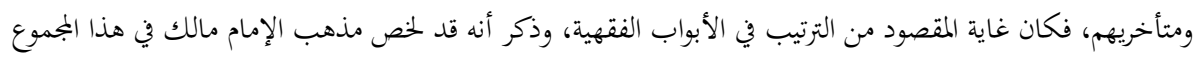
وعلى القرب من محاذاته 3. ومن هنا بدأ ترتيب أبواب الفقه في المذهب المالكي، وكل من جاء بعد الإمام ابن شاس من المالكية اعتمد

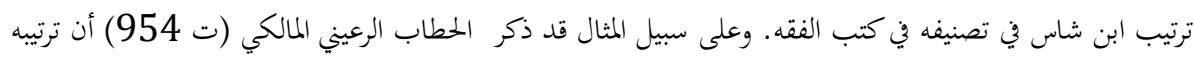

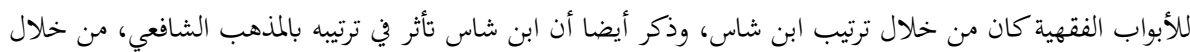

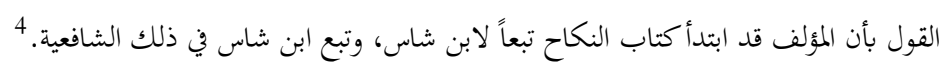
وبالنظر إلى موضوعات مختصر خليل (ت 767هـ) من خلال شرحه للخرشي نجد أيضا مدى تأثر المالكية بترتيب الإمام ابن شاس والذي تأثر بترتيبات الإمام الغزالي الشافعي 5.

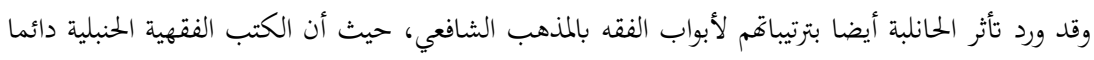

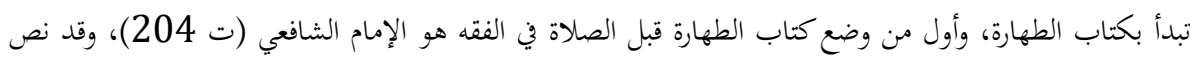

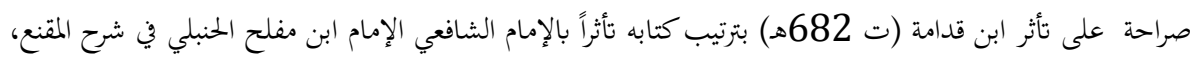

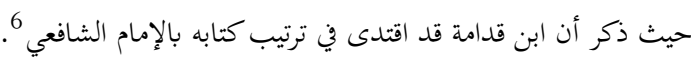

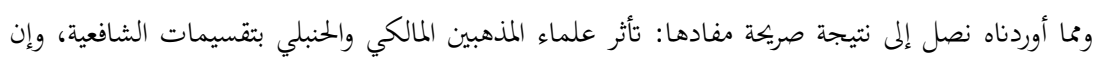

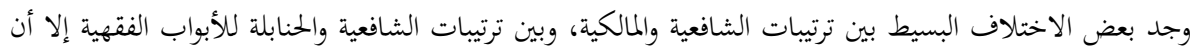

1 عبد الوهاب أبو سليمان، ترتيب الموضوعات الفنهية ومناسباته في المذاهب الأربعة، ط: الأولى (مكة، سلسلة بحوث الدراسات

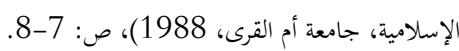
2 جلال الدين ابن شاس، عقد الجواهر الثمينة في مذهب عالم المالمدينة، ط: الأولى، ( لبنان، دار الغرب، 2003) حققه: حميد لحمر،

3 3 ابن شاس، الجواهر الثمينة، 4/1 
العناوين الرئيسية كانت متطابقة وطريقة التقسيمات للأبواب الفقهية متشابه، تتغير فيها عناوين داخلية بسيطة تقديما

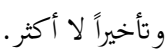

وفي عموم كتب هذه المذاهب الثلاثة، كان تقسيمهم لموضوعات الفقه تقسيما رباعيا -أي منقسما إلى أربعة

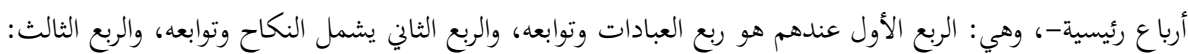

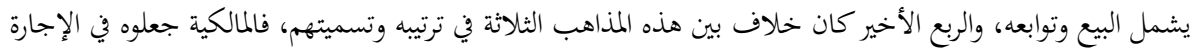

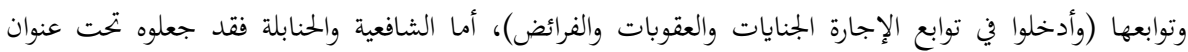

ويككن للتأكد من هذه المعلومات الإطلاع على كتاب ختصر خليل كنموذج لترتيب الأبواب الفقهية عند

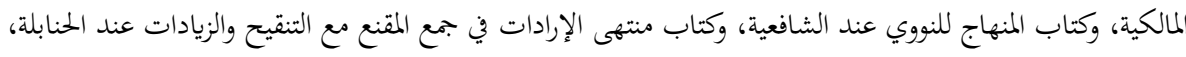
وسوف نقوم بإدراج ترتيب هذه الكتب في نهاية البحث هذا.

وبمذا نكون قد بيّنا سبب الاقتصار بالمقارنة بين ترتيب الأبواب الفقهية عند الحصيري وعند الشافعية.

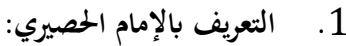

1.1. السمه: هو أبو بكر محمد بن إبراهيم بن أنوش بن إبراهيم بن محمد البخاري الحنفي 8 بـائ. . 1.2 1.3. مشايخه: ذكر الإمام الذهبي في كتابه تاريخ الإسلام 10: أنه روى وسمع لكل من:

عمر بن منصور البخاري الحافظ، وهو: عمر بن منصور بن أممد بن محمد بن منصور الحافظ أبو حفص

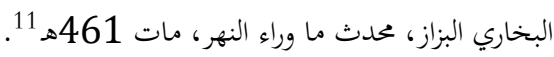
عبد الكريم بن أبي حنيفة، وهو عبد الكريم بن أبي حنيفة بن العباس أبو المظفر الأندقي البخاري، شيخ الحنفية

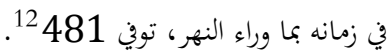
عبد الواحد الزبيري المعمّر، وهو عبد الواحد بن عبد الرممن بن القاسم بن إسماعيل، أبو محمد الزبيري الورسكي

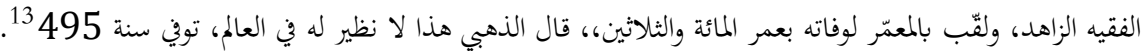

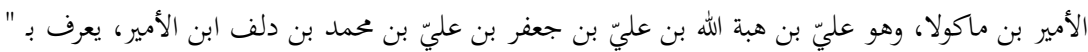

7 أديب الضمور، تقسيم موضوعات الفقه وترتيها في كتب المذاهب الفقهية الأربعة، ( السعودية، مجلة العلوم الشرعية واللغة العربية،

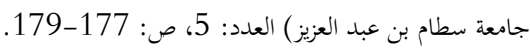

8 8 عبد القادر القرشي، الجواهر المضية في طبقات المنفية، (باكستان، مير عمد كتاب خانه)، 3/2.

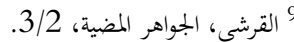

10 شمس الدين الذهبي، تاريخ الإسلام ووفيات المشاهير والأعلام، ط: الأولى، تحقيق: بشار معروف، (دار الغرب الإسلامي)، 828/10.

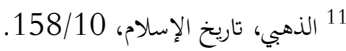

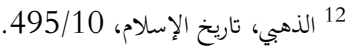




$$
\begin{aligned}
& \text { بالوزير سعد الملك ابن ماكولا" توفي سنة 487 } \\
& \text { وقد اتفقت جميع الكتب التي أوردت معلومات عن الإمام الحصيري أنه كان تلميذاً للإمام ثمس الإئمة } \\
& \text { السرخسي رمه الله تعالى. }
\end{aligned}
$$

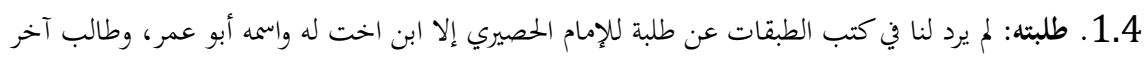

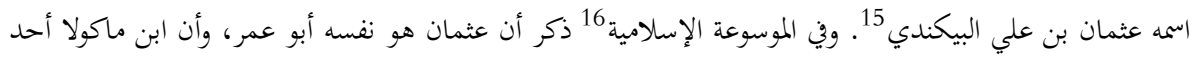

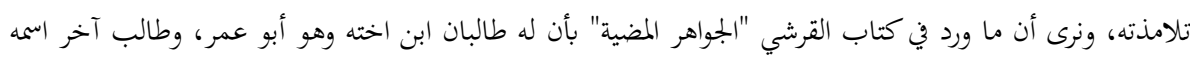

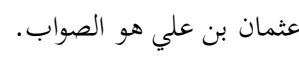

$$
\begin{aligned}
& \text { ويبدو أنه وقع خطأ في بعض المصادر بذكرهم أن ابن ماكولا كان أحد طلبته كما أورد ذلك أمدا اوزيل } 17 \text { في }
\end{aligned}
$$

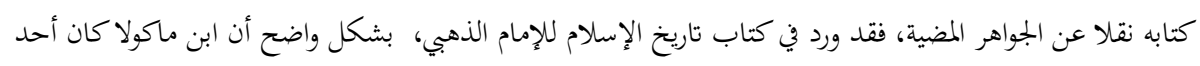

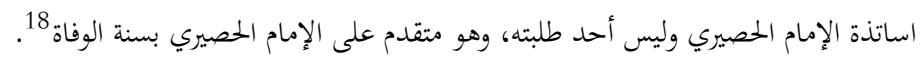

$$
\begin{aligned}
& \text { 2. ن نظرة على فهرس مخطوط } 19 \text { كتاب الحاوي: }
\end{aligned}
$$

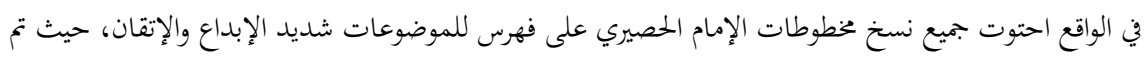

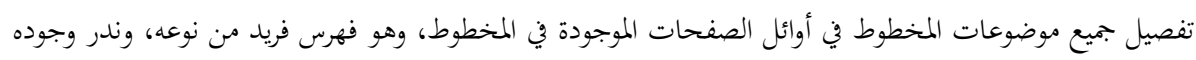

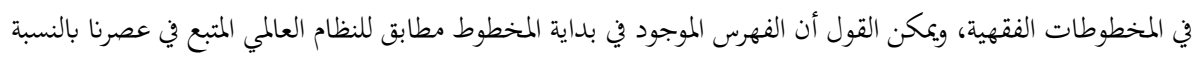

$$
\begin{aligned}
& \text { لفهرسة موضوعات الكتب -كما أسلفنا-. }
\end{aligned}
$$

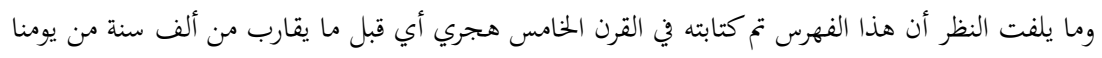

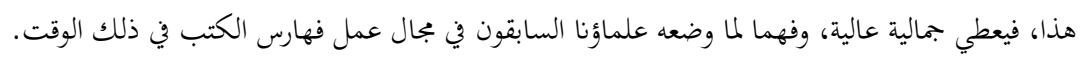

$$
\begin{aligned}
& \text { وموضوعات المخطوط كما وردت في فهارس المخطوطات التي وقفنا عليها كما يلي. } \\
& \text { اشتمل كتاب الحاوي في الفتاوى على خمسة أقسام: } \\
& \text { القسم الأول: العبادات: } \\
& \text { 1- الصلاة. } \\
& \text { 14 الذهبي، تاريخ الإسلام، 581/10. }
\end{aligned}
$$

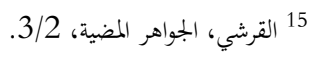


منهجية الإمام الحصيري في ترتيب الأبواب الفقهية من خلال كتابه الحاوي في الفتاوى -دراسة مقارنة

$$
\begin{aligned}
& \text { - 2- 2 - الصوم. }
\end{aligned}
$$

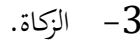

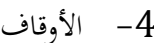

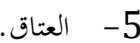

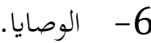

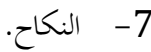

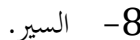

$$
\begin{aligned}
& \text { 9- الأضحية والذبائح. } \\
& \text { 10- الوديعة. } \\
& \text { 11- العارية. } \\
& \text { 12 - المبة. } \\
& \text { 13- 13 - اللقطة. } \\
& \text { القسم الثاني في المعاملات والمباحات: }
\end{aligned}
$$

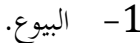

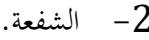

$$
\begin{aligned}
& \text { 3- 3 - 3 الإجارة. }
\end{aligned}
$$

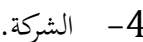

$$
\begin{aligned}
& \text { 5- - 5 - المزارعة. } \\
& \text { 6- - 6 - المضاربة. }
\end{aligned}
$$

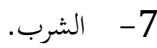

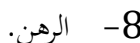

$$
\begin{aligned}
& \text { القسم الثالث: في الخظورات والمكروهات: } \\
& \text { 1- 1 - 1 الطلاق. }
\end{aligned}
$$

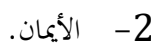

$$
\begin{aligned}
& \text { 3- 3- الغصب. } \\
& \text { 4- 4 - الضمان. } \\
& \text { 5- الحظر والإباحة والكراهة والإجازة. }
\end{aligned}
$$




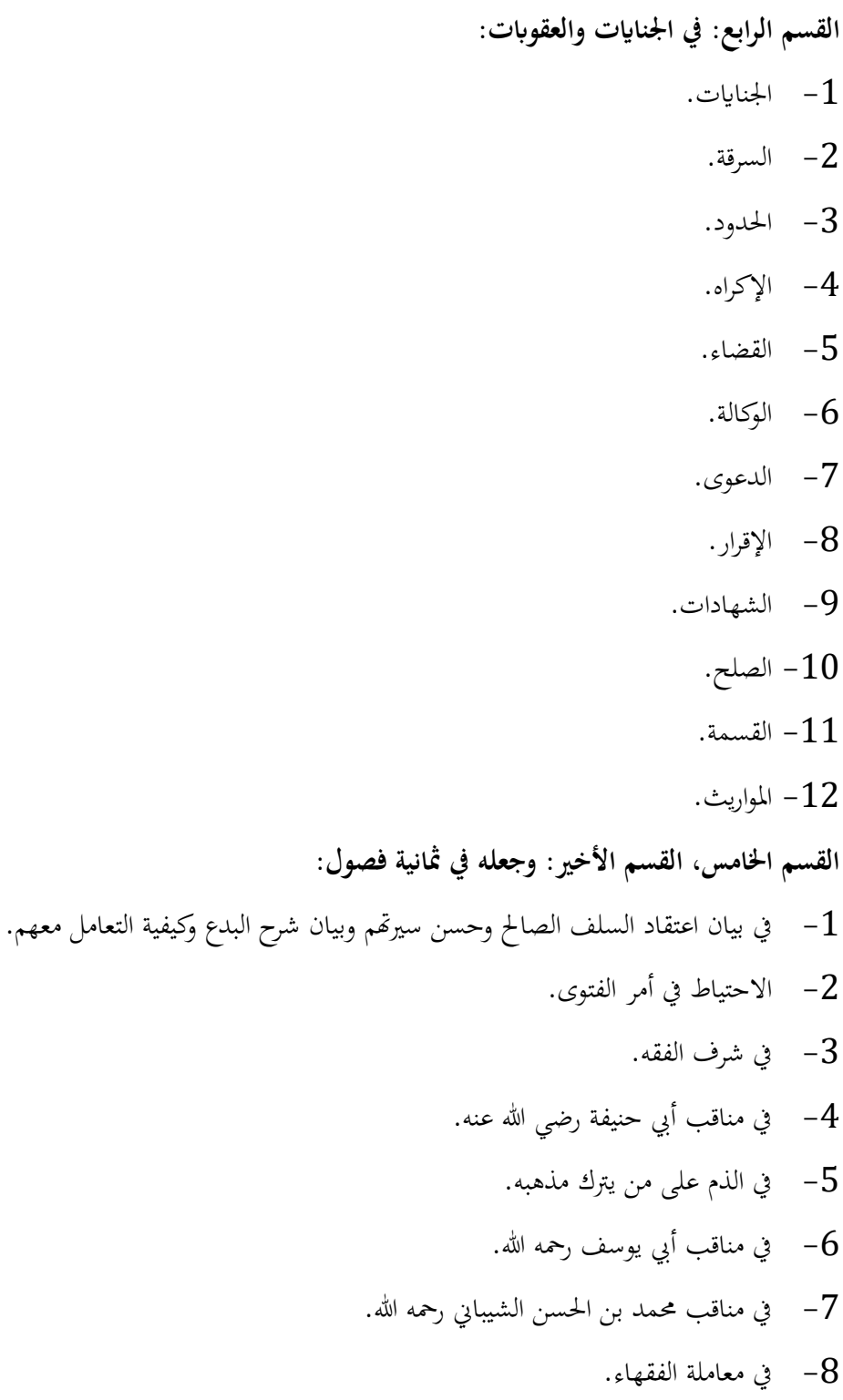

والذي وقفنا عليه من خلال اطلاعنا على نسخ المخطوطات هو: اختلاف نسخة (جار الله علي)، في فهرسة الموضوعات من خلال تقسيم الموضوعات إلى ثلاثة أقسام لا أربعة وهي" العبادات، المعاملات والمباحات، والمكروهات والمخظورات"، وباقي النسخ جعلتها من أربعة أبواب كما قمنا بعرضه في أعلاه، حيث أن نسخ المخطوط اعتبرت باب

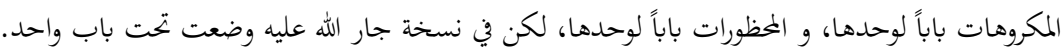
3. تحليل تقسيمات الأبواب الفقهية عند الإمام الحصيري. 


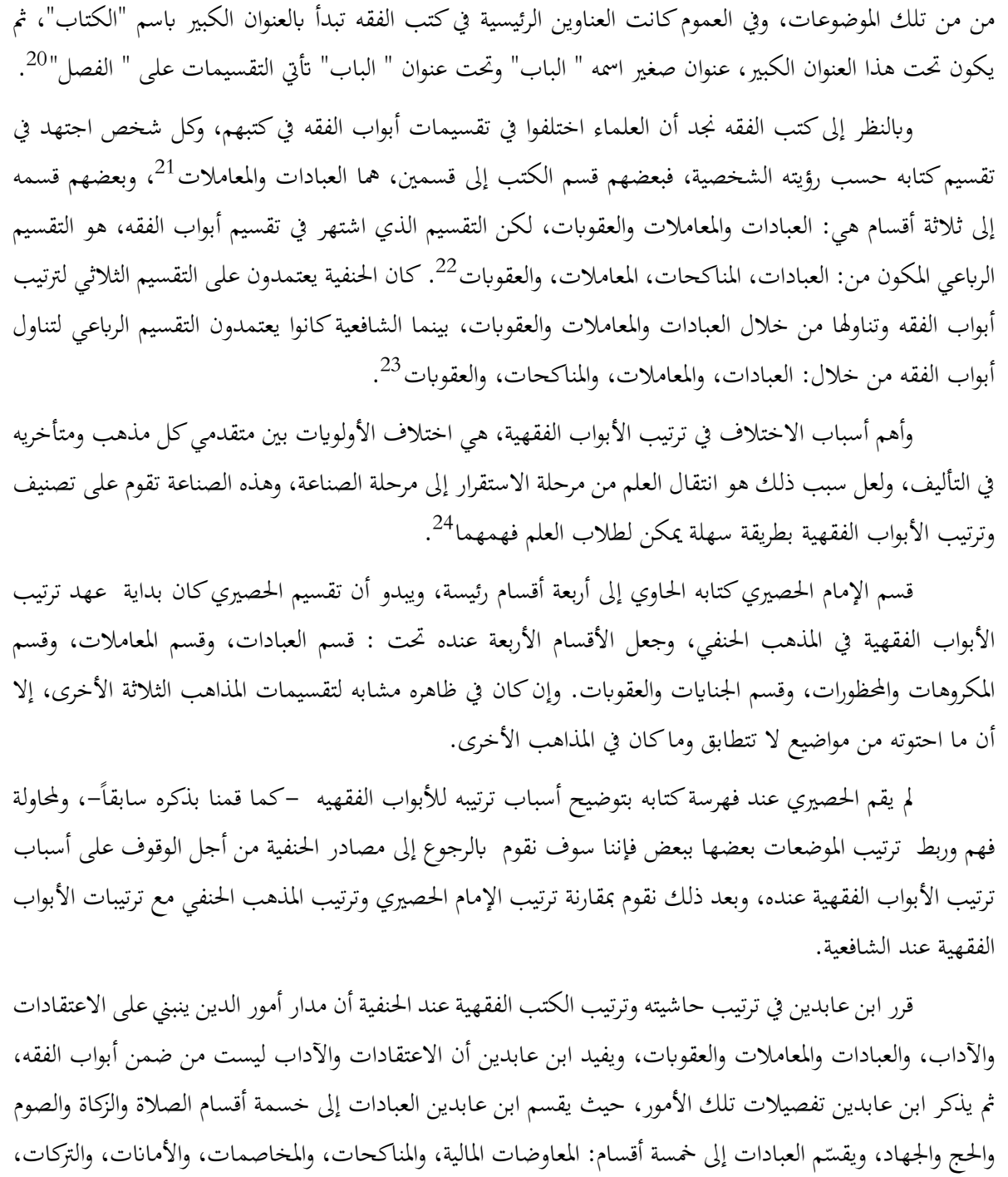

${ }^{20}$ Bilal Aybakan, "Fürû‘ Fıkıh Sistematiğgi Üzerine", Marmara Üniversitesi İlâhiyat Fakültesi Dergisi 31 (2006/2), 6.

${ }^{21}$ Aybakan, "Fürû' Fıkıh Sistematiği Üzerine", 8.

22 Yıldız Demir-Ahmet M. Peşe, "İslâm Hukuk Sistematiği ve Literatürü", İslâm Hukuku El Kitabı (Ankara: Grafiker Yayınları, 2015), 107. Bekir KARADAĞ, İslâm Hukuku Sistematiğine Dair Bir İnceleme (Kitâbu'n-Nikâh Örneği), (Harran, Harran Üniversitesi İlahiyat Fakültesi Dergisi, sayı:43), 111:

${ }^{23}$ Karadağ, İslâm Hukuku Sistematiğine Dair Bir İnceleme, 111.

$$
\text { 24 الضمور، تقسيم موضوعات الفقه، ص: } 200 .
$$




\section{Zehra ELBAKRİ \& Shaker JABARİ}

ثم القسم الثالث وهو العقوبات، ويجعله في خمسة أقسام: القصاص، وحد السرقة، والزنا، والقذف، والردة. 25 وفي تقديم

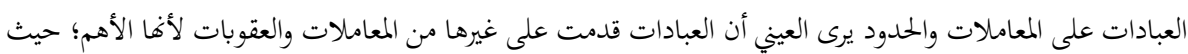

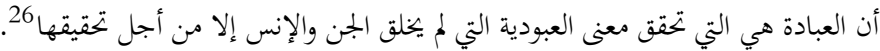
ويرى الشافعية أن أحكام الشرع متعلقة بالعبادات أو بمعاملات أو بمناكحات أو بجناية 27. ولهذا كان تقسمهم

$$
\text { لأبواب الفقه على أربعة أرباع لكل ما يحتاجه الناس من أحكام الشرع. }
$$

وسبب هذا التقسيم عند الشافعية هو نظرهم لغرض بعثة النبي صلى الله عليه وسلم، وهذا الغرض كان انتظام أحوال الناس في معاشهم ومعادهم، وهذه الأحوال لا يمكن انتظامها إلا بكمال قواهم الإدراكية وقواهم الشهوانية وقواهم

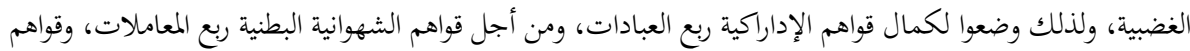

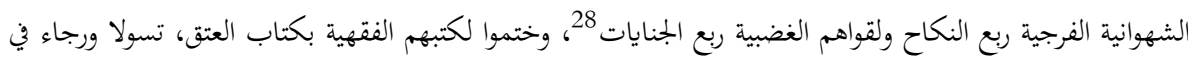
أن يعتقوا من النار.

وقد ذكر الشافعية أن تقديم العبادات بسبب تعلقها بالأشرف، وبعدها تناولوا المعاملات لشدة الحاجة إليها والتعامل فيها، وبعدها المناكحة لدوفا في الحاجة عن المعاملات، ثم ذكروا الجنايات لقلة وقوعها بالنسبة لما قبلها، فرتبوها ترتيبا تصاعديا من الأهم إلى المهم 30

ومن هنا يتبين لنا كيف قام الشافعية بتقسيم كتبهم الفقهية إلى أربعة أقسام، فالعبادات والتي تشمل (الطهارة والصلاة والجنائز والزكاة والصيام والاعتكاف والحج)، جاءت فئن القسنم الأول لشرفها وحاجة الناس لكمال قواهم

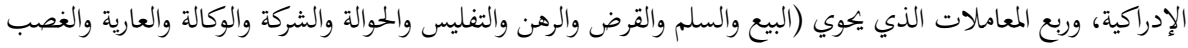

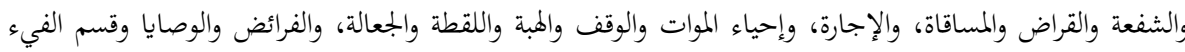

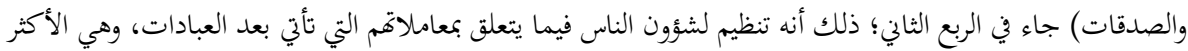

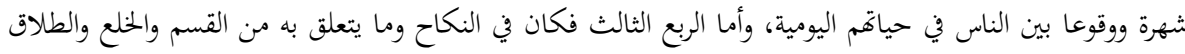
والرجعة والإيلاء والظهار والكفارة واللعان والعدد، والرضاع، والنفقات)، من أجل صيانة حاجة الناس الشهوانية في فروجهم، وأما الربع الأخير فقد تناولوا فيه الجنايات وما تعلق بها من ( جراح وديات ودعوى الدم والبغاة والردة والزنا

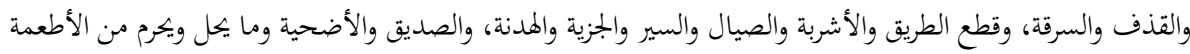

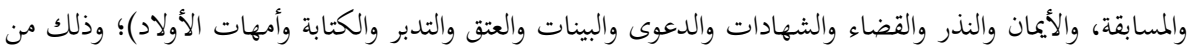

25 محمد أمين بن عابدين، رد الختار على الدر المختار المعروب بـ" حاشية ابن عابدين"، ط: الثانية، ( بيروت، دار الفكر، 1992)،

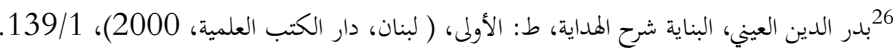

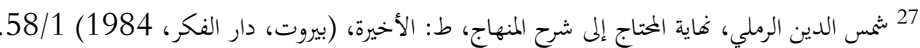

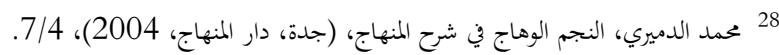


منهجية الإمام الحصيري في ترتيب الأبواب الفقهية من خلال كتابه الحاوي في الفتاوى -دراسة مقارنة

أجل مراعاة قواهم الغضبية، ولأهما الأقل وقوعا بين الناس بعد المناكحات.

وهنا يظهر لنا أن الحنفية والشافعية اتفقوا في تقديم باب العبادات على ما سواها إلا أن الحنفية جعلوا الجهاد

في قسم العبادات والشافعية جعلوه في الربع الرابع تحت باب السير لتعلقه بالدماء.

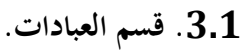

وقد ساق الإمام الحصيري كتاب الصلاة، والصوم، والزكاة في بداية قسم العبادات، وبحسب إطلاعنا فإن جميع

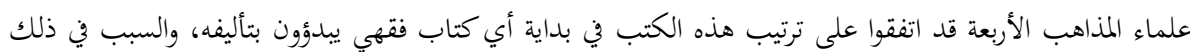

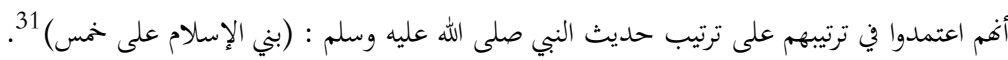

وبعدها تناول الإمام الحصيري موضوعات" الوقف، والأضحية، والعتق" تحت باب العبادات، وذلك أن في هذه

الأمور الثلاثة معنى العبادة32. ويطلق على هذه العبادات مصطلح العبادات الفرعية، وهذه الموضوعات اختلف الفت العلماء

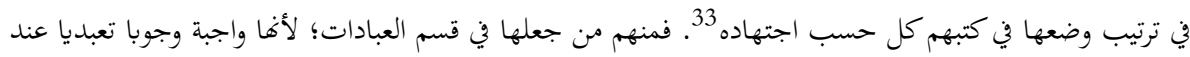

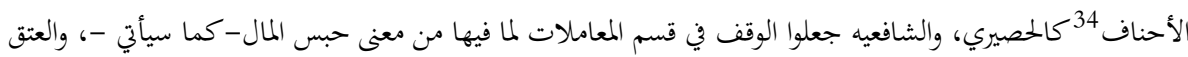

$$
\text { وضعوه في آخر كتبهم. -كما ذكرنا-. }
$$

ويؤخر متأخروا الحنفية الوقف إلى بعد كتاب الشركة؛ لأنه مناسب للشركة باعتبار أن المقصود بكل منهما

الانتفاع بما يزيد على أصل المال، إلا أن الأصل في الشركة مستبقى في ملك الإنسان، ويف الوقف مخرج عنه عند الأكثر 35.

ولكن الشافعية وضعوا الوقف في ربع المعاملات بعد باب البيع، ولعل المناسبة في ذلك من حيث أن في كل

منهما معنى إزالة الملك، ففي الوقف يزول الملك عن الواقف بعد حكم الحاكم، من غير أن يدخل في ملك الموقوف عليك عليه،

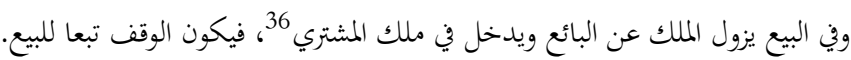

والشافعية جعلوا الوقف بعد إحياء الموات، وتعليل ذكر الوقف عَقِبَ إحْيَاءِ الْمَوَاتِ عند الشافعةِ مُنَاسَبَِّهِ لَهُ في

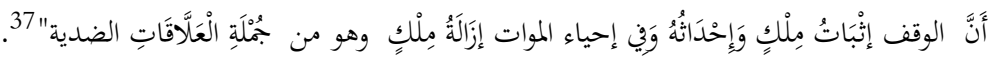

ومن هنا يمكننا أن نفهم سبب وضع الشافعية لكتاب الوقف في قسم المعاملات؛ لإعتبارهم أن الوقف عبارة

$$
\text { عن معاملة مالية، وفيها حبس للمال لصالح جهة ما. }
$$

ذهب علماء الحنفية في ترتيب كتاب النكاح إلى طريقتين، فبعضهم جعل باب النكاح بعد كتاب العبادات

$$
\begin{aligned}
& 31 \text { الدمياطي، إعانة الطالبين، 29/1. } \\
& \text { 32 ابن عابدين، حاشية ابن عابدين، 3/3. }
\end{aligned}
$$

33 Karadağ, İslâm Hukuku Sistematiğine Dair Bir İnceleme, 111-112.

34 35 فخر الدين الزيلعي، تبيين الحقائق شرح كنز الدقائق وحاشية شلبي، ط: الأولى، (القاهرة، المطبعة الكبرى الأميرية، 1313هـ) ، 
مباشرة، والكثير من المختصرات جعلوا البيوع بعد كتاب العبادات، وبعد البيوع تناولوا مسألة النكاح 38 البكات والذين قدموا

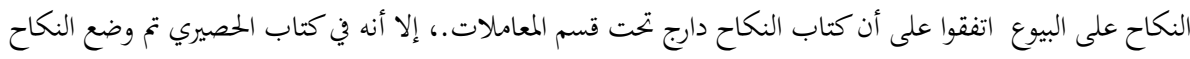

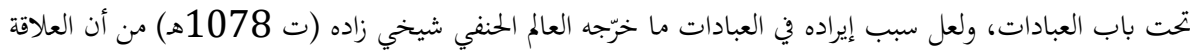

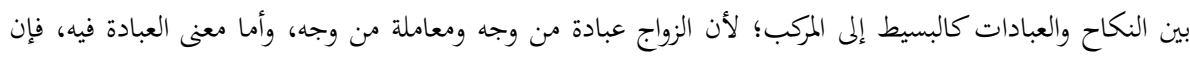

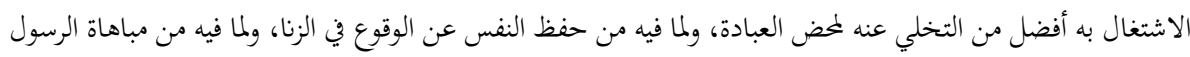

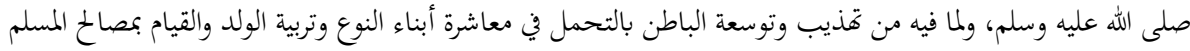

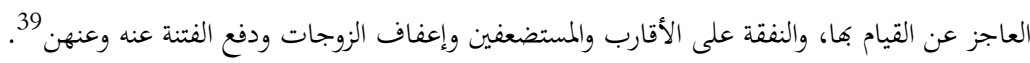

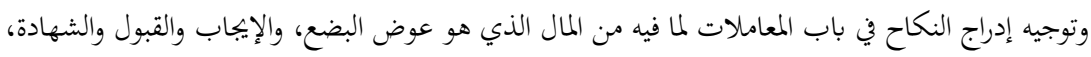

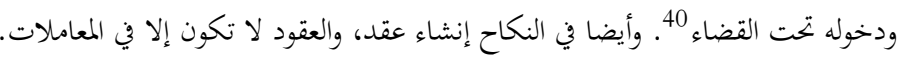

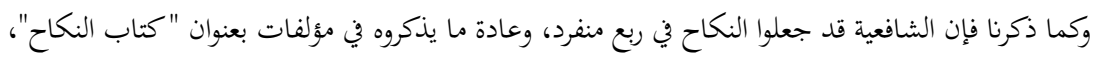

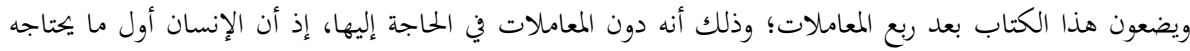

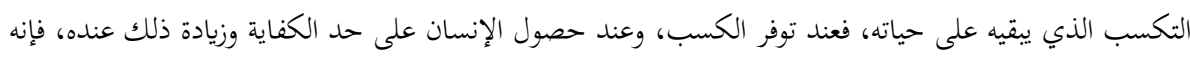

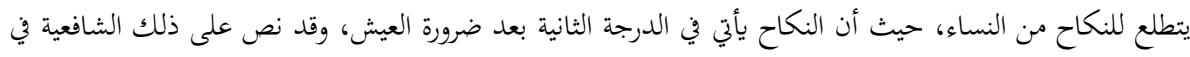

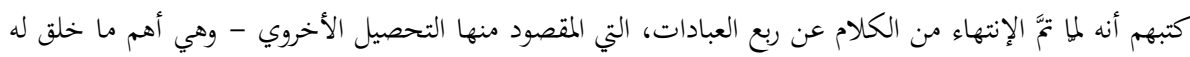

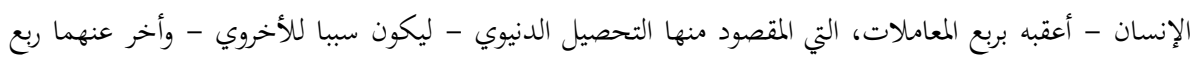

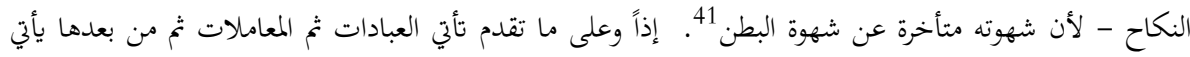
النكاح؛ وسبب ذلك أنه يأتي بعد استيفاء شهوة البدن. يشتمل كتاب النكاح عند الشافعية على عدة موضوعات هي: (الصداق، الخلع، الطلاق، الرجعة، الإيلاء،

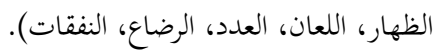

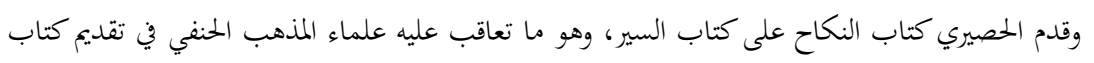

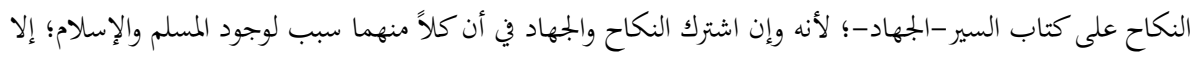

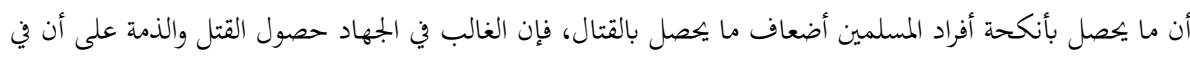

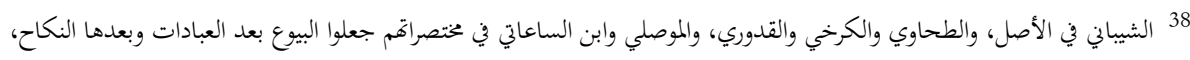

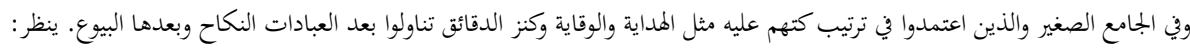
Orhan Ençaka. "Hanefî Fıkıh Literatüründe Gelenek Oluşturan Kayıp Bir Metin: Muhtasarü'l-Kerhî”. İslâm Araştırmaları Dergis, sayı: 37, (2017, s 13. Karadağ, İslâm Hukuku Sistematiğine Dair Bir İnceleme, 113.

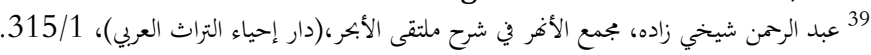

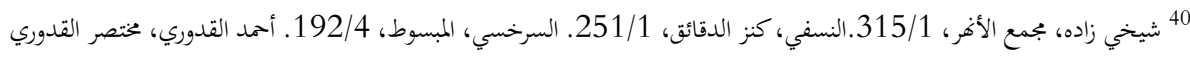

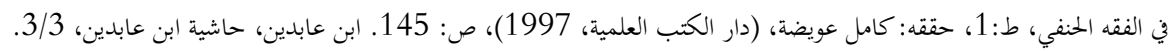

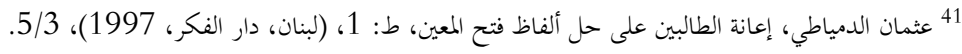

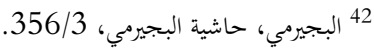


كونه سبباً لوجود المسلم تساعحا نظراً إلى أن تجدد الصفة بمنزلة تحدد الذات33.

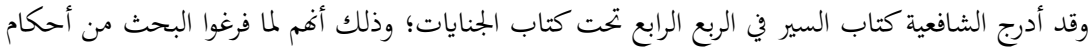

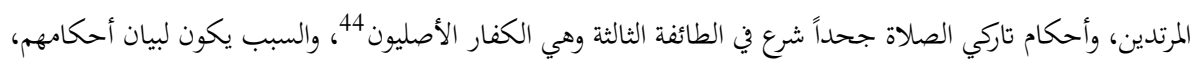

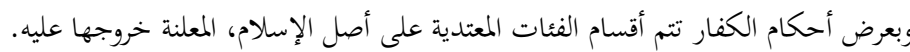

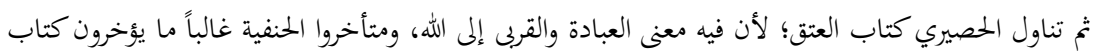

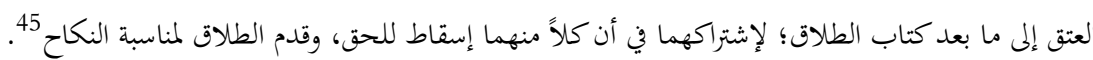
وفي كتب الشافعية دائما يؤخرون كتاب العتق إلى آخر أبواب الفقه، -أي في آخر ربع الجنايات- قبل الثبل أحكام

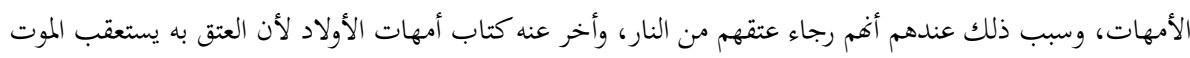

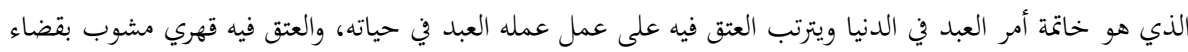

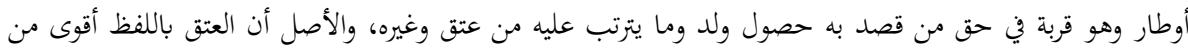

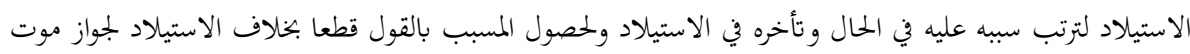

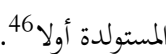

ويلاحظ هنا أن تأخير الشافعية لكتاب العتق تأخير معنوي ولا رابط بينه وبين ما سبقه من الموضوعات. وأما الأضحية فوردت في كتاب العبادات عند الحصيري؛ لأنما مقرونة بالحج؛ حيث شرط تقديمها في وقت ذبكها أن تذبح في أيام النحر قربة لله تعالى 47.

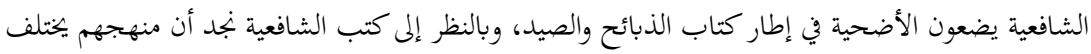

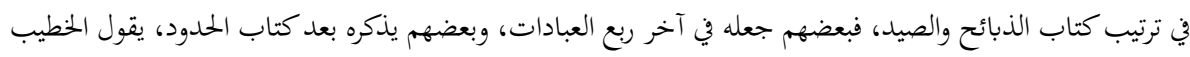

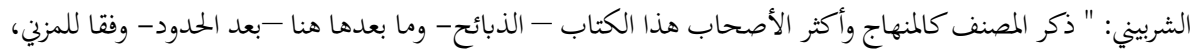

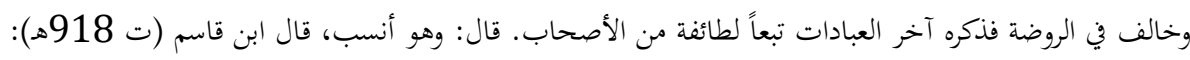

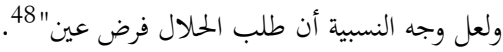

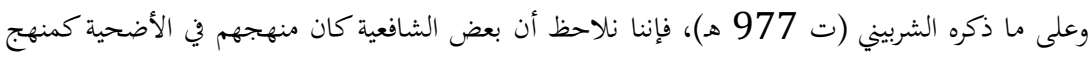

$$
\text { الإمام الحصيري في جعل الأضحية تحت قسم العبادات. }
$$

تم ذكر الإمام الحصيري كتاب الوديعة، وفي كتب الفقه الحنفي يتم سرد كتاب الوديعة بعد كتب الإقرار

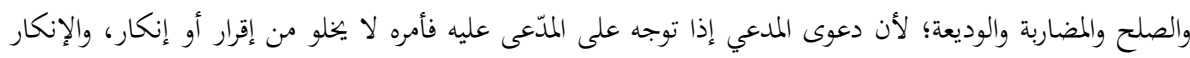

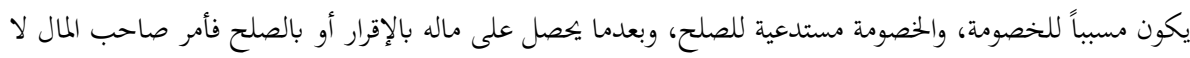

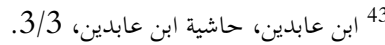

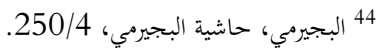
45

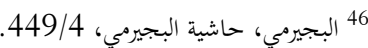




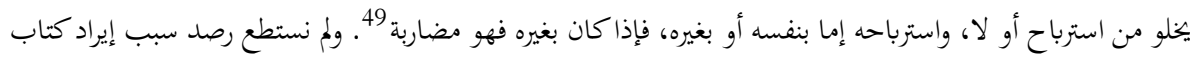

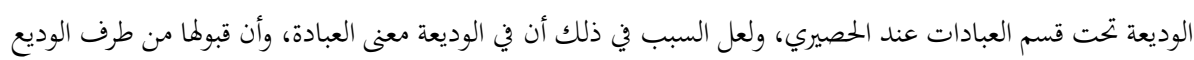

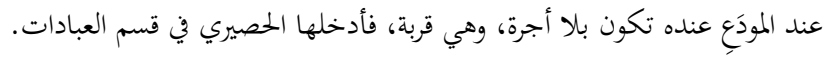

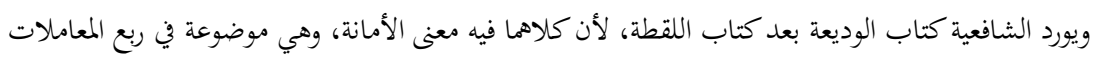

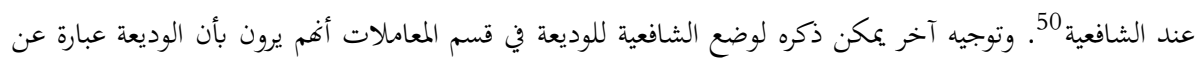

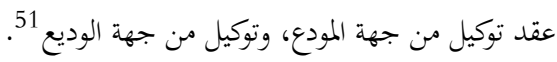

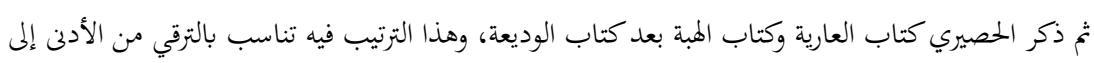

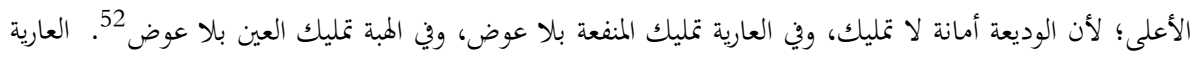

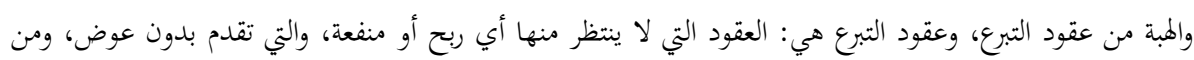

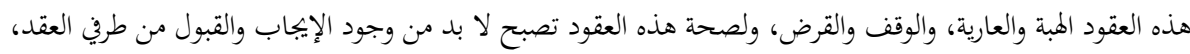

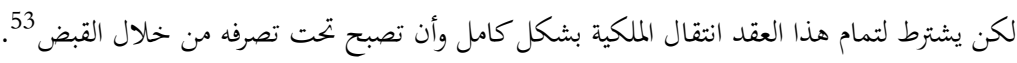
ولأن هذه العقود لم يكن فيها مكتسب دنيوي وأن القيام مجا كان من أجل القربة وتطوعا، فمن هنا يدخل فيها

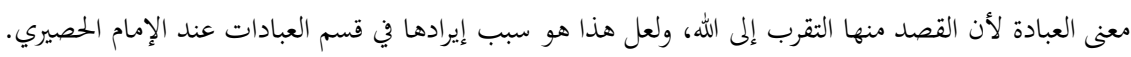

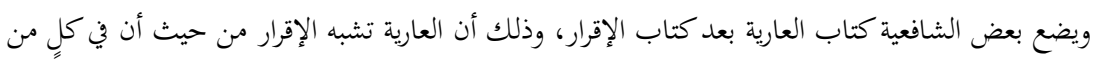

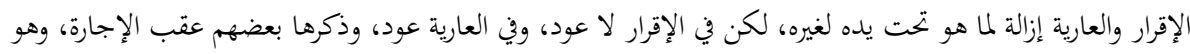

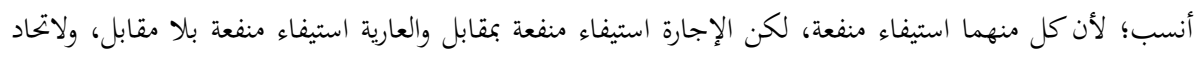

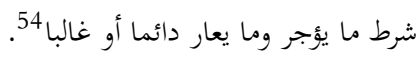

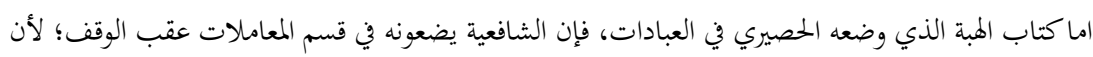

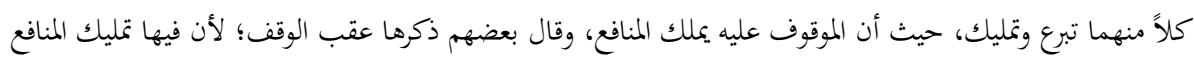

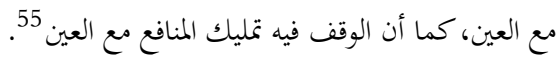
أما كتاب اللقطة فيوردها الأحناف عادة بعد كتاب اللقيط؛ لوجود معنى اللقط فيهما، إلا أن اللقيط اختص آلصع

$$
\text { بالمنبوذ من بني آدم، واللقّطة اختصت بالمنبوذ من المال } 56 .
$$

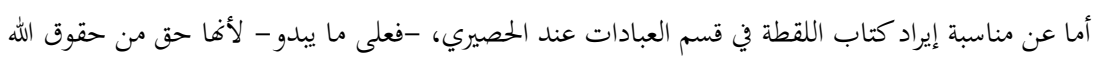

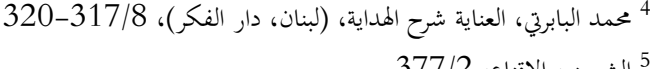

$$
\begin{aligned}
& 51 \text { إبراهيم الشيرازي، المهذب في فقه الإمام الشافعي، ( بيروت، دار الكتب العلمية)، 184/2. } \\
& \text { 52 البابرتي، العناية، 484/8. }
\end{aligned}
$$

53 Arif Atalay, İslam Hukukunda Teslim Tesellüm (Kabz) (Kayseri: Kimlik Yayınları, 2016), 109 


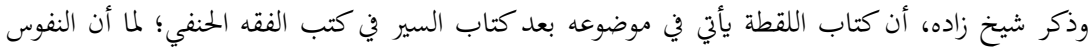

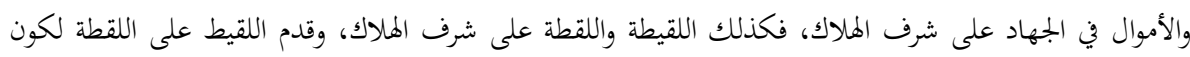

النفس أعز من المال، وقدم السير عليهما؛ لأن في الجهاد إعلاء كلمة الله تعالى 58.

ولعل الحصيري رتب كتب السير والأضحية والوديعة والعارية والهبة واللقطة من باب أن كلا منهم فيه حفظ

من الهلاك، وجميعها يدخل في معنى العبادة لما فيه من قربة إلى الله تعالى.

$$
\text { أو لأغخا حق من حقوق الله تعالى. }
$$

والشافعية يضعون اللقطة عقب المبة كما ذكرنا سابقا، وذلك أن اللقطة نوع من الكسب كما أن المبة نوع منه

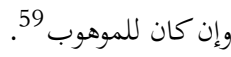

أما كتاب الوصايا، فلعل وروده في قسم العبادات؛ لأن بعض العلماء يرون أن الوصية فرض، وبعضهم يرى بأها

فإذا كانت الوصية واجبة أو فرض عند بعض العلماء، فيصبح من المفهوم ورود كتاب الوصايا عند الحصيري

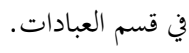

والشافعية يضعون كتاب الوصايا عقب الفرائض أو عقب الحوالة، وسبب ذكرها عقب الفرائض المتعلقة بالموت؛

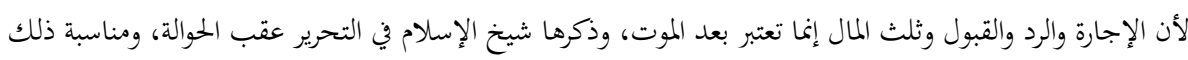

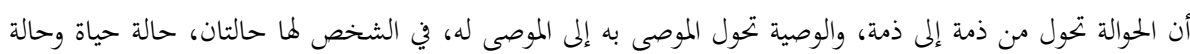

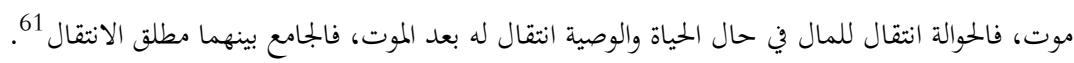

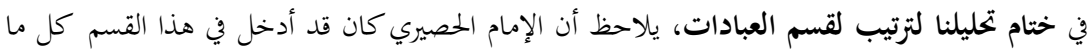

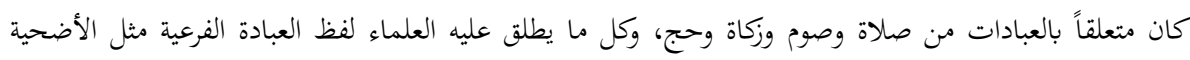

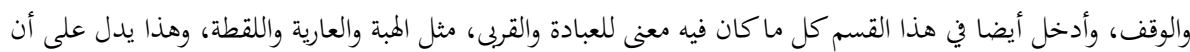

$$
\begin{aligned}
& \text { الإمام الحصري كان يتوسع في معنى العبادة وما يدخل فيها. }
\end{aligned}
$$

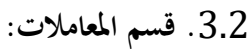

$$
\begin{aligned}
& \text { بدأ الإمام الحصيري قسم المعاملات والمباحات بكتاب البيوع. }
\end{aligned}
$$

سبب إيراد كتاب البيوع بعد قسم العبادات، هو أن مشروعات الشارع منقسمة إلى حقوق الله تعالى خالصة،

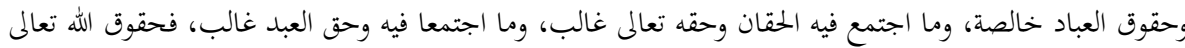

$$
\begin{aligned}
& 57 \text { ابن عابدين، حاشية ابن عابدين، 500/4. }
\end{aligned}
$$

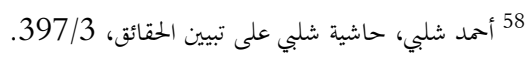

$$
\begin{aligned}
& \text { 69 البجيرمي، حاشية البجيرمي، 273/3. }
\end{aligned}
$$

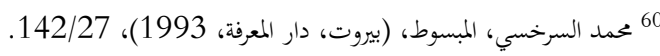

$$
\begin{aligned}
& \text { 31 البجيرمي، حاشية الجيرمي، 333/3. }
\end{aligned}
$$




\section{Zehra ELBAKRİ \& Shaker JABARİ}

عبادات وعقوبات وكفارات، فيبتدأ بحقوق الله تعالى الخالصة ، ثم تأتي حقوق العباد وهي المعاملات ووقع ترتيب أول أقسام حقوق العباد في البيع فئ.

ويبدو أن الحصيري كان ينتهج هذا التمهيد في تقسيم كتابه، فبعد ذكر حقوق الله (العبادات) شرع في ذكر حقوق العباد (المعاملات)، وابتدأ بكتاب البيوع.

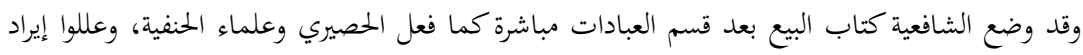

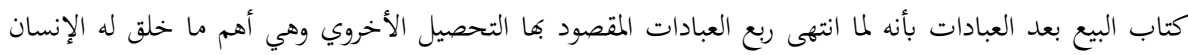

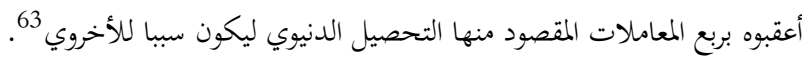
ويلاحظ أن الحنفية والشافعية اتفقوا على تعليل سبب قدوم قسم المعاملات بعد العبادات. ثم ألحق الإمام الحصيري كتاب البيوع بكتاب الشفعة، ويبدو أن إلحاق كتاب الشفعة بالبيوع لقيام حق الشفعة وتعلقه بالبيع.

وفي عموم كتب الفقه الحنفي يأتي كتاب الشفعة بعد كتاب الغصب؛ لأنه تملك لمال الغير بغير رضاه، وكذا الغصب، وقدم بعض العلماء الأحناف الغصب على الشفعة، لكثرة وقوعه، وأنه قد يدخل في العقار والمنقول، بخلاف

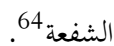
ويرى الإمام البابرتي أنه كان لا بد من ذكر كتاب الشغعة قبل كتاب الغصب؛ لأن الشفعة حلال والغصب

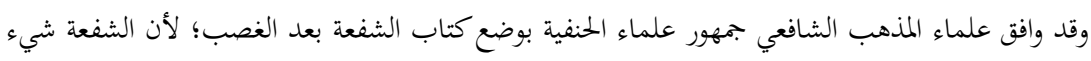

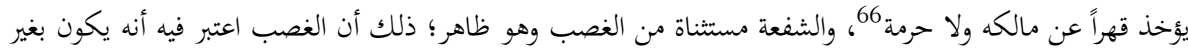
حق وبعدها ذكر كتاب الإجارات، ولعل كتاب الإجارة جاء لاحقاً لكتاب البيوع والشفعة؛ لما فيه معنى التمليك

وفي كتب الفقه الحنفية، يتم ذكر كتاب الإجارة بعد كتابي العارية والهبة، للتناسب بالترقي من الأدن إلى الأعلى،

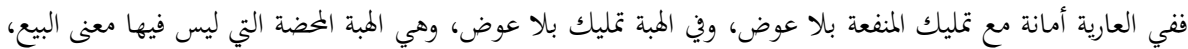

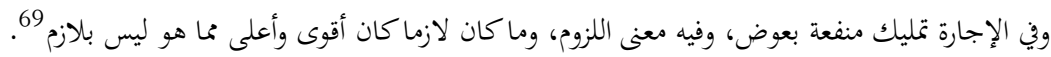


ويورد الشافعية الشفعة قبل باب الإجارة70، ويتناولون بعد الإجارة كتاب الجعالة وذلك لاشتراك الإجارة

$$
\text { والجعالة في غالب الأحكام }
$$

بعدها ذكر كتاب الشركة، وفي عموم كتب الأحناف كتاب الشركة يأتي بعد كتاب المفقود لوجود مناسبة خاصة

بالمفقود من حيث إن نصيب المفقود من مال مورثه مختلط بنصيب غيره كاختلاط المالين في الشركة.72.

ولم نقف على مناسبة تبويب الشركة بعد كتاب الإجارات عند الحصيري، ولكنها داخلة في باب المعاملات، فلا يشترط أن يكون هناك علاقة مباشرة بالإجارات لتذكر بعدها مباشرة.

ويضع الشافعية كتاب الشركة بعد باب الضمان، ومناسبة ذلك ضمان أحد الشريكين في بعض الصور 73أي

$$
\text { في بعض حالات الشركة. }
$$

ثم ذكر الحصيري كتاب المزارعة، والمزارعة واحدة من أنواع الشركات، وقد تكون إجارة أيضاً 74.

ولذلك يمكن فهم مناسبة وضع كتاب المزارعة بعد كتابي الشركات والإجارات عند الحصيري في هذا الإطار، حيث أنها إما أن تكون مزارعة وإما أن تكون إجارة.

وفي كتب الفقه الحنفي عند المتأخرين، يضعون كتاب المزارعة بعد كتاب القسمة، وذلك ملا كان الخارج من الأرض من أنواع ما يقع فيه القسمة ذكروا المزارعة عقب القسمة؛ ولأن الأرض بعض ما يجري فيه القسمة، ثم بعد قسمة

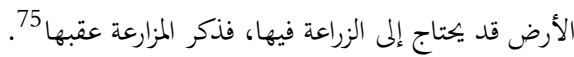

ويتناول الشافعية موضوع المزارعة عقب الجعالة، ويعللون ذلك أن في كل من المزارعة والجعالة عملاً مجهولاً7، وتكون الجهالة في المدة أو ذات العمل. وبعدها تناول الإمام الحصيري كتاب المضاربة، وقد رتبت كتب الفقه الحنفي كتاب المضاربة بعد كتاب الصلح، ووجه المناسبة بين الصلح والمضاربة، أن كالاً منهما مشتمل على الاسترباح، أما المضاربة فإن مبناها على هذا، وأما الصلح

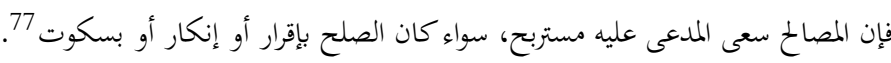
ويبدو أن الإمام الحصيري اتسق مع نفسه بإتباع المضاربة بعد كتاب الشركة على أساس أها نوع من أنواع الشركات كما فعل بكتاب المزارعة. ويتناول الشافعية كتاب المضاربة تحت عنوان "القراض"، ويتناوها بعضهم عقب الشفعة، وبعضهم عقب الوديعة، والذين تناولوها عقب الشعفة عللوا ذلك بأن الحاجة داعية إلى جواز كل منها، لكن الحاجة في الشفعة لدفع الضرر،

$$
\begin{aligned}
& 70 \text { الدمياطي، إعانة الطالبين، 119/3 وما بعدها. } \\
& 71 \text { الجيرمي، حاشية البجيرمي، 220/3. }
\end{aligned}
$$

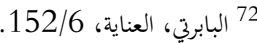

$$
\begin{aligned}
& 73 \text { البجيرمي، حاشية البجيرمي، 124/3. } \\
& \text { 74 البلدحي، الاختيار لتعليل المختار، 74/3. } \\
& 75 \text { الشلبي، حاشية شلبي، 278/5. } \\
& 76 \text { البجيرمي، حاشية البجيرمي، } 3 \text { / } 227 . \\
& \text { 77 العيني، البناية، 42/10. }
\end{aligned}
$$




\section{Zehra ELBAKRİ \& Shaker JABARI}

والحاجة في المضاربة لنفع المالك والعامل، والذين تناولوها عقب الوديعة عللوا مناسبة ذكرها بعد الوديعة بأن الشفعة

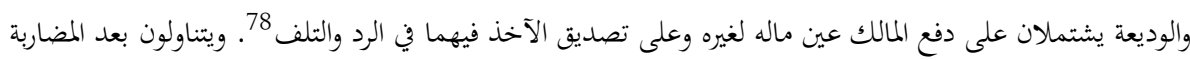

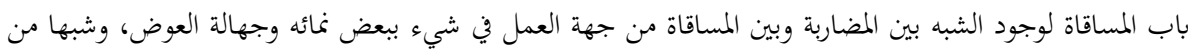
الإجارة من جهة اللزوم والتأقيت 79.

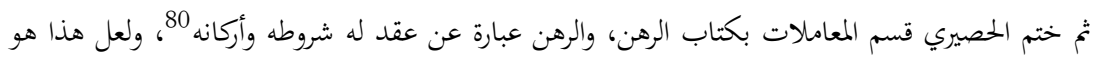
السبب الذي جعل الحصيري يضعه في قسم المعاملات.

ويتناول الشافعية الرهن قبل باب الحجر، ووجه مناسبة ذلك أن الراهن يكون من جملة المحجور عليهم 81. وفي ختام قسم المعاملات، وبنظرة عامة على الأبواب التي وضعها الإمام الحصيري تحت هذا القسم نرى أن

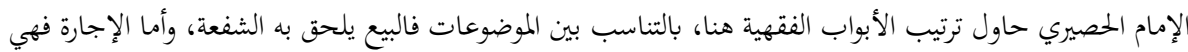

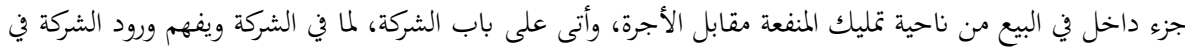

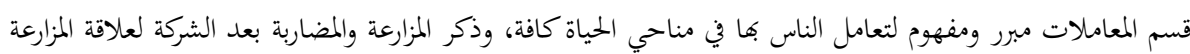
والمضارابات التشارك بين أكثر من شخص، وبعدها أتى على كتاب الشرب، والشرب لا بد له من وجود مزراعة أو مضاربة في العمل في الأرض فهنا يظهر لنا تلك العلاقة الخفية لوضع الشرب بعد كتابي المزراعة والمضاربة، وذكر الرهن

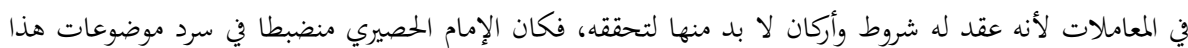

\section{3. الخظورات والمكروهات.}

تعددت تسميات أئمة الحنفية في عنونة موضوعات هذا القسم، فبعضهم ذكره تحت قسم الكراهية، فمن الكتب التي خصته بلفظ "الكراهية" الجامع الصغير، ومختصر الطحاوي، وكتاب الهداية، وكتاب كنز الدقائق، وبعض الأحناف

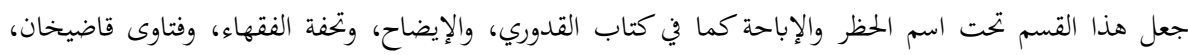

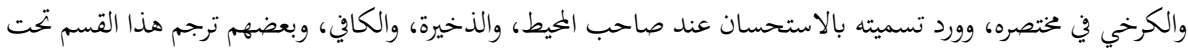

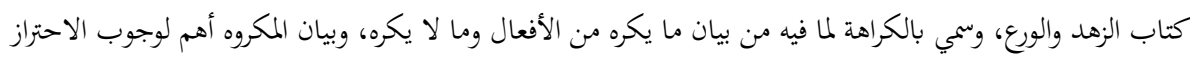

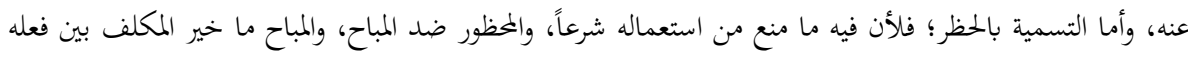
وتركه من غير استحقاق ثواب ولا عقاب، وأما تسميته بالاستحسان فلما فيه من بيان ما حسنه الشرع وقحبه، ولفظة

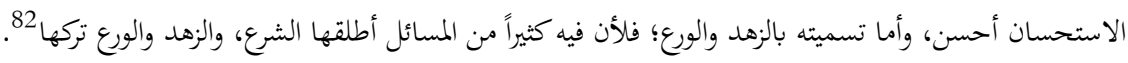
ومما سبق فإن الإمام الحصيري هنا يعرض الكتب التي يذكر فيها ما يكره من الأفعال وما لا يكره، وما يمنع استعماله شرعاً وما لا يمنع، وأول ما بدأ به الإمام الحصيري في هذا القسم كتاب الطلاق، ويبدو أن منطلق الحصيري 80 علاء الدين الكاساني، بدائع الصنائع في ترتيب الشرائع، الطبعة: الثانية، ( لبنان، دار الكتب العلمية، 1986)، 135/6، البهائ، 81 82 محمد ملا خسرو، درر الحكام شرح غرر الأحكام، (دار إحياء الكتب العربية)، 309/1.الزيلعي، تبيين الحقائق، 10/6. 
بذكر كتاب الطلاق في أول قسم الخظورات والمكروهات هو حديث النبي صلى الله عليه وسلم : ( أبغض الحلال إلى الله الطلاق)

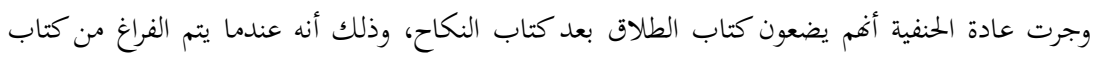

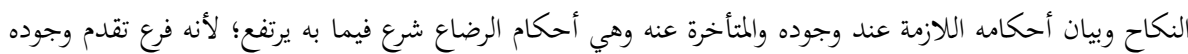

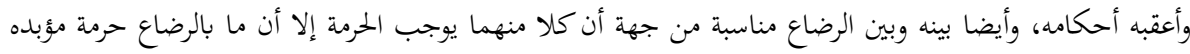

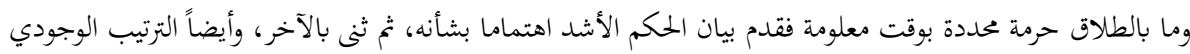

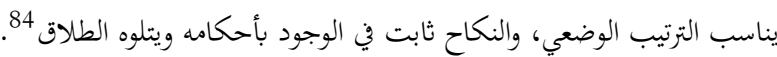
ويعرض الشافعية موضوع الطلاق في ربع المنكاحات بعد باب الخلع، وسبب ذكره عقب الخلع عندهم؛ لأن كلا منهما فيه معنى الفرقة 85

ثم بعدها يتناول الإمام الحصيري كتاب الأيمان، وكتاب الأيمان يتم تناوله بعد الطلاق في كتب الحنفية؛ لأن

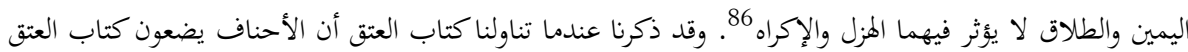

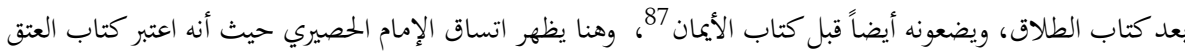

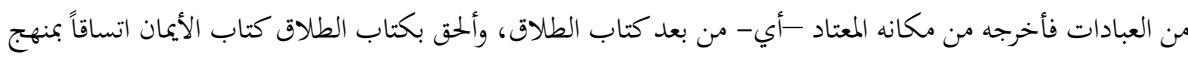
الحنفية في تناول هذين الموضوعين.

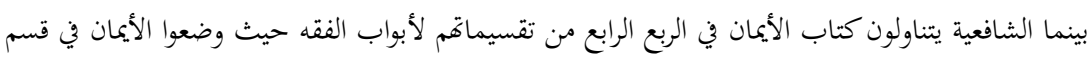

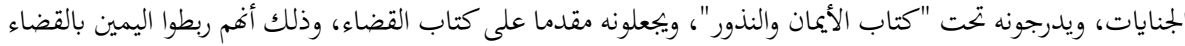

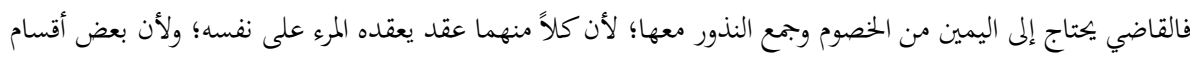

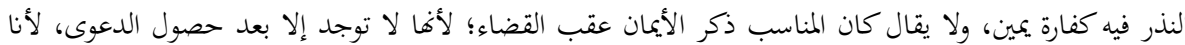

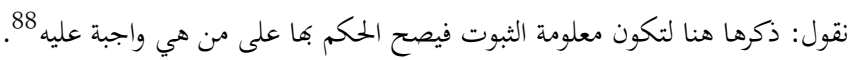
ثم تناول بعد كتاب الأيمان كتاب الغصب، وكما ذكرنا سابقاً فإن الأحناف يضعونه في قسم المعاملات قبل

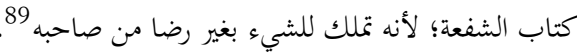
ومناسبة وجوده في المكروهات والمخظورات عند الحصيري واضحة السبب؛ لأنه مما يكرم ويخظر القيام به. أما الشافعية فإنم يجعلون الغصب بعد العارية، وذلك لأن العارية توجب الضمان، والغصب كذلك، ولان كلا

83 أبو داود السجستاني، سنن أبي داود، ححقه شعيب الأرنؤوط، ط1، ( دار الرسالة، 2009)، حديث رقم: 2179.

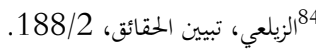

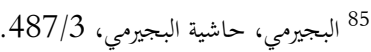

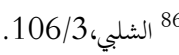
87

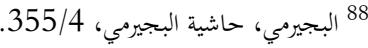

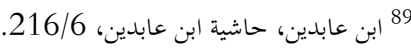


من العارية والغصب فيه وضع اليد على مال الغير 90.

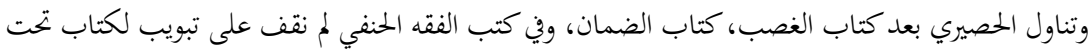

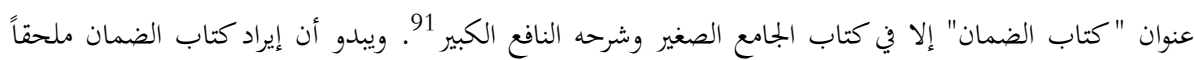

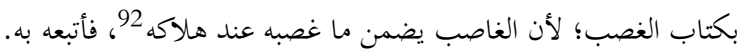

والضمان عند الشافعية يأتي بعد باب الحوالة؛ لأن كلا منهما يترتب عليه قطع النزاع؛ ولأن في الضمان والحوالة

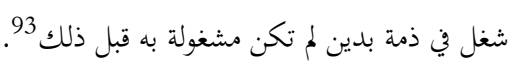

وبعدها تناول كتاب الحظر والإباحة والكراهة والإجازة، وتناول في هذا الكتاب المسائل المتعلقة بالتناول من

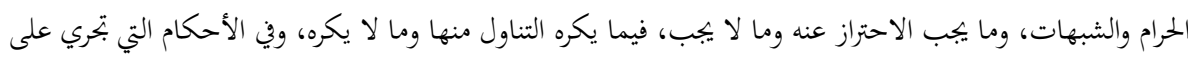

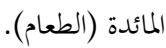

ورابط هذه الموضوعات مرتبط بما قبلها ارتباطا معنويا لا ارتباطا موضوعيا، فبعد ما ذكره الإمام الحصيري من

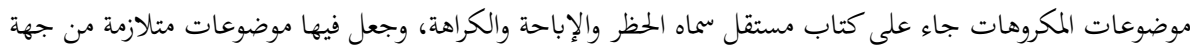

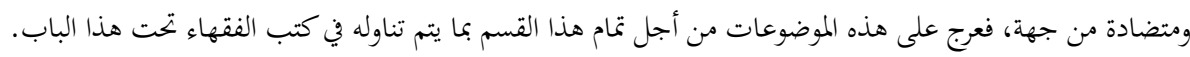

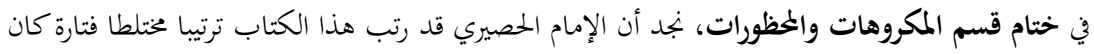

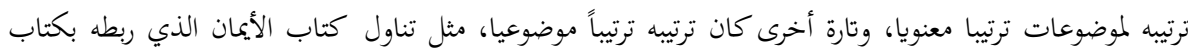

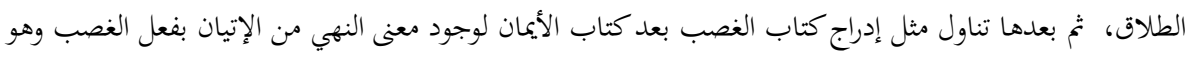

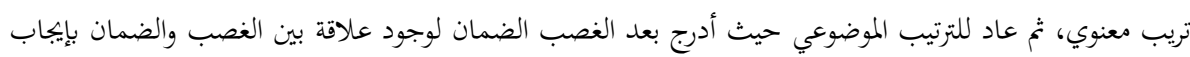
ضمان المغصوب عند هلاكه، ثم يعود إلى الترتيب المعنوي من خلال تناول كتاب الحظر والإباحة والكراهة والإجازة.

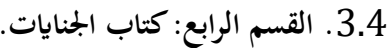

في الفتح القدير أتبع كتاب الرهن بكتاب الجنايات، وهو ترتيب متأخري الأحناف، وعلل ذلك أن أن كل واحد

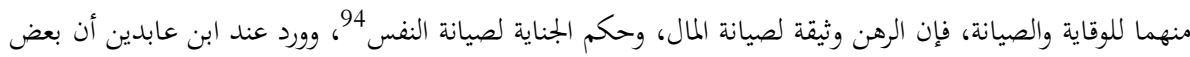

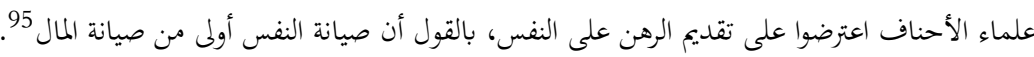

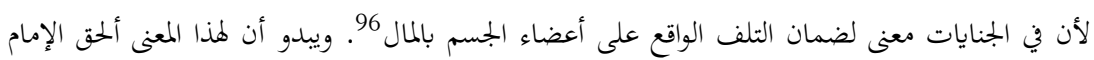

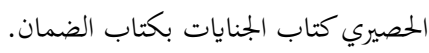

وعند الشافعية يرد كتاب الجنايات بعد ربع المناكحات، وذلك كما ذكروا أن بعد العبادة والمعاملة والمناكحة 
تأتي الجناية لقلة وقوعها بالنسبة لما قبلها، فرتبوها على هذا الترتيب 97. وسبب ذكرها باسم الجنايات وليس الجراحات

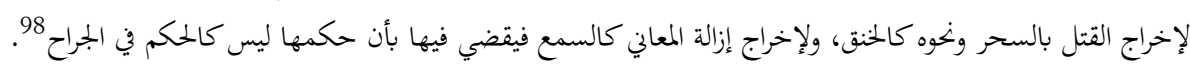

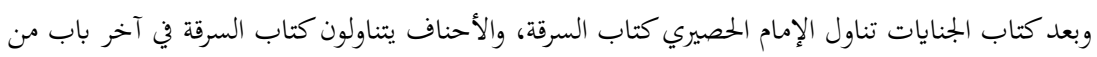

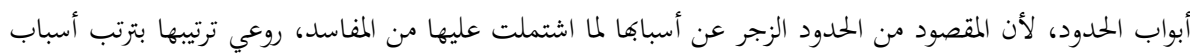

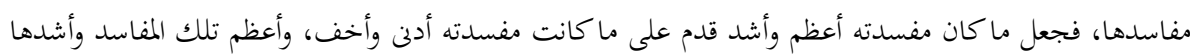

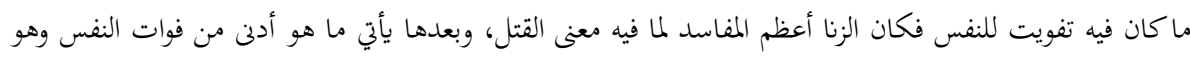

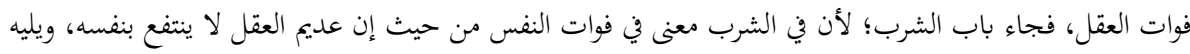

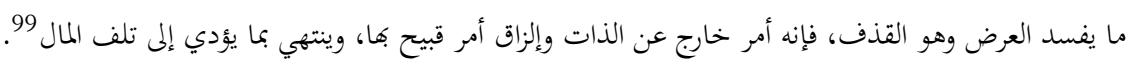

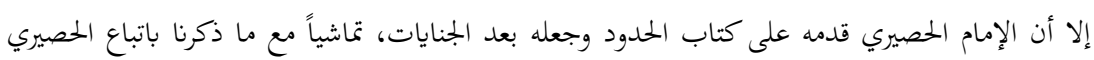

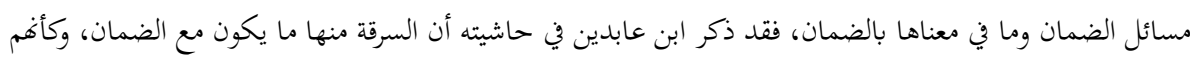

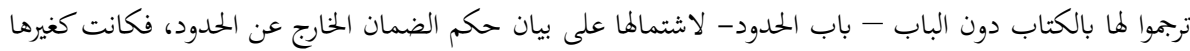
من وجه فأفردت عنها بكتاب متضمن لأبواب 100.

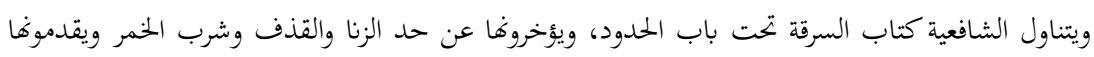

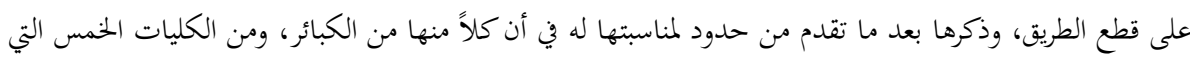

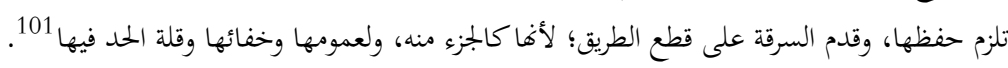

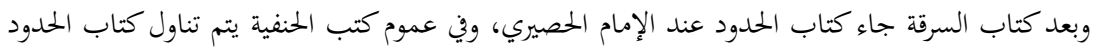

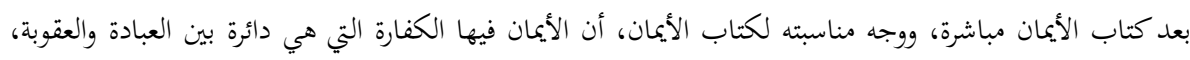

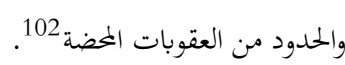

إلا أن الحصيري بسوقه كتاب السرقة بعد كتاب الحدود، توافقا مع ما جاء من أن حفظ المال يلزمه أيضاً حفظ

النفس.

ويذكر الشافعية كتاب الحدود بعد كتاب القتل، وذلك أن القتل أفحش الكبائر 103.

ثم تناول كتاب الإكراه، وكتاب الإكراه في كتب الأحناف يأتي بعد كتاب الولاء، وذلك لماكان مان من آثار العتق

$$
\text { والعتق لا يؤثر فيه الإكراه، فناسب ذكر الإكراه عقيب الولاء. }
$$

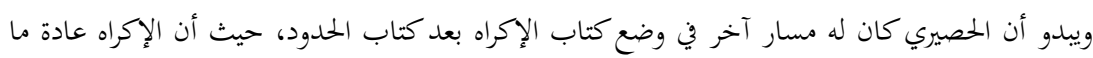

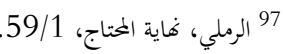

98 الدمياطي، إعانة الطالبين،

99 99 ابن الممام، فتح القدير، العانئ الطالبن، 352/5-353.

100 ابن عابدين، حاشية ابن عابدين، ابن الفير،

101

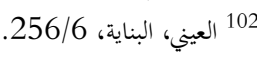

103 البجيرمي، حاشية البجيرمي، 167/4. 


\section{Zehra ELBAKRİ \& Shaker JABARİ}

بكون فيه إضرار بالنفس أو المال كما ذكر ذلك الإمام السمرقندي من أن الإكراه نوعان: نوع يوجب الإلجاء والإضرار

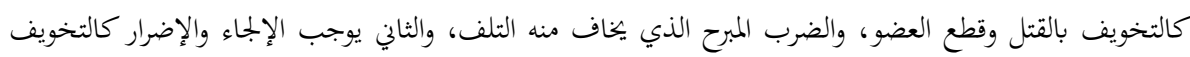

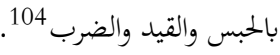

فلما كان الإضرار بالجسد المسمى جناية، والإضرار بالمال يسمى سرقة، والإضرار بالنفس بالزنا أو القتل وغيره

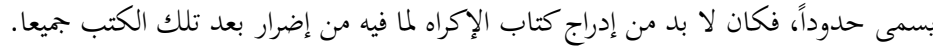

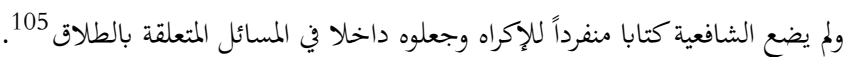
ثم تناول الإمام الحصيري كتاب القضاء، وعادة كتب الفقه الحنفي أن تضع كتاب القضاء بعد كتاب البيوع،

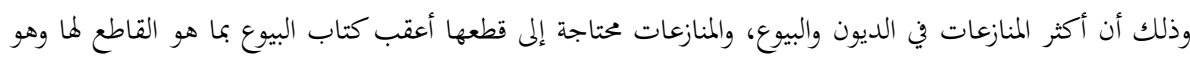
القضاء 106.

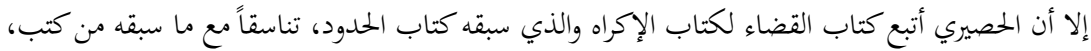
وأن الإكراه لا يرفعه إلا القاضي، ولأن الحدود لا يمكن إيقاعها إلا بقضاء القاضي، أتبع هذه الكتب بكتاب القاب القضاء. ويتناول الشافعية كتاب القضاء تحت عنوان " كتاب الأقضية والشهادات"، ويعلوها في آخر كتبهم بعد كتاب

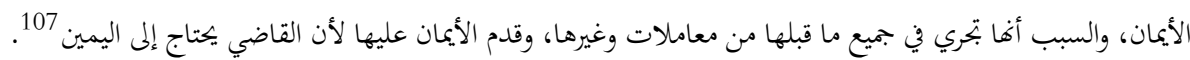
تم تناول الإمام الحصيري كتاب الوكالة بعد كتاب القضاء، وعموم كتب الحنفية تتناول كتاب الوكالة بعد كتاب الشهادة وذلك أن كالً من الشاهد والوكيل ساع في تحصيل مراد غيره 108.

لكن الحصيري على ما يدو أتبع كتاب الوكالة بكتاب القضاء لأن الوكالة نوعان، أحدها يكون في حقوق الله،

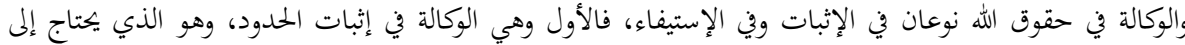

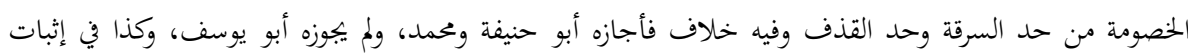

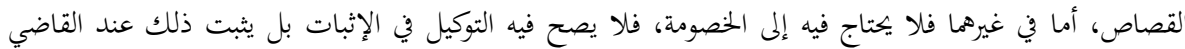

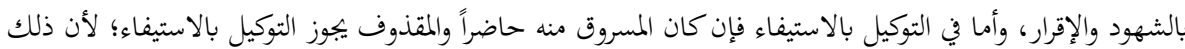
إلى الأمام وهو لا يقدر أن يياشر بنفسه على كل حال وال 109.

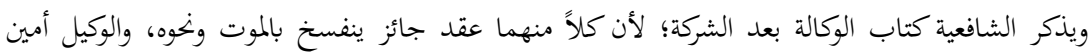

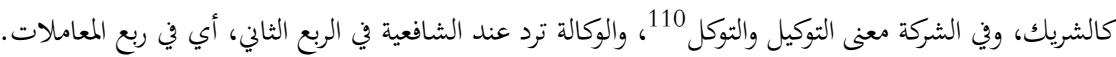

104

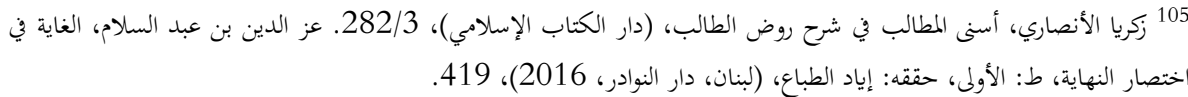
106

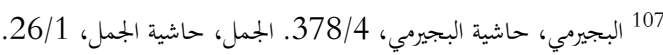
108 
ثم ذكر كتاب الإمام الحصيري كتاب الدعوى ملحقا بكتاب الوكالة، وذلك أنه لما كانت الوكالة بالخصومة

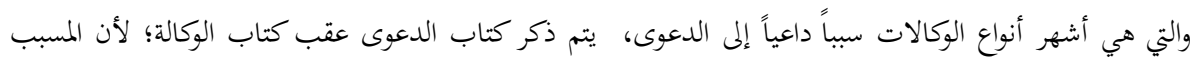

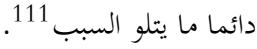
والشافعية يتناولون كتاب الدعوى في باب الأقضية والشهادات، وذلك أن الدعوى والبينات لا تكون إلا عند

قاض أو محكم 112.

وبعد كتاب الدعوى ذكر الحصيري كتاب الإقرار، ومناسبة كتاب الإقرار بعد كتاب الدعوى أن المدعى عليه

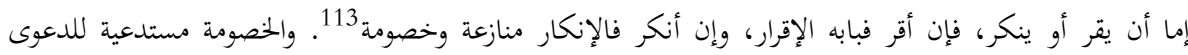
والقضاء.

والشافعية يجعلون كتاب الإقرار بعد الوكالة، لشبهه بالوكالة من حيث أن المقر قبل إقراره كان متصرفاً فيما بيده

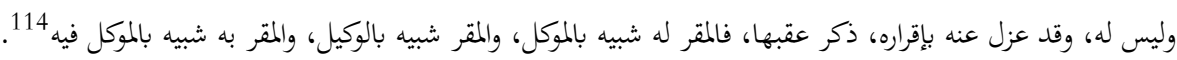
ثم جاء كتاب الشهادات، بعد كتاب الإقرار، يذكر علماء الحنفية كتاب الشهادة متعقبا لكتاب القضاء، رغم

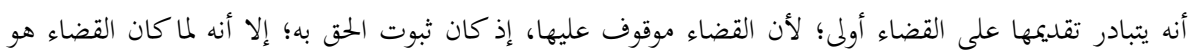

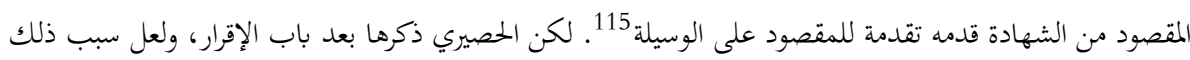

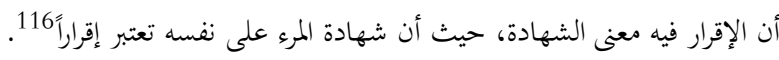
والشافعية يتناولون كتاب الشهادات بعد الدعوى؛ لأخا تكون بعدها، ومن قدم الشهادة نظر للتحمل؛ لأنه يكون قبل الدعوى 117. ثم ذكر الحصيري كتاب الصلح بعد كتاب الشهادات، والربط بين الصلح وبين كتاب الإقرار، أن كتاب الإقرار

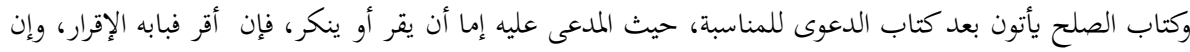

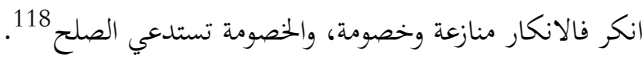

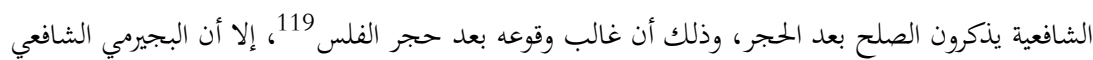

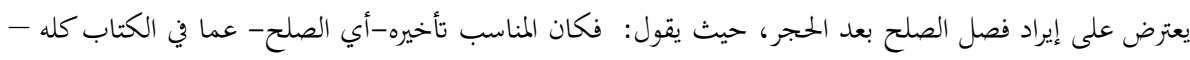
111 1ابن الممام، فتح القدير، 152/8.

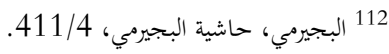
113 113 ابن المجام، فتح القدير، البحري، 317/8.

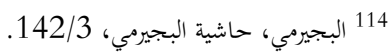

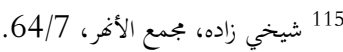

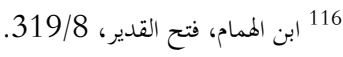

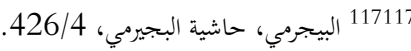
118 ابن الممام، فتح القدير، الفية البحري، 317/8. 
أي المعاملات-؛ لأنه يجري في غالبها، فيكون بيعا وسلما وهبة وإجارة" 120.

ثم ذكر الحصيري كتاب القسمة، وفي ترتيب الأبواب الفقهية عند الأحناف يذكرون كتاب القسمة عقب

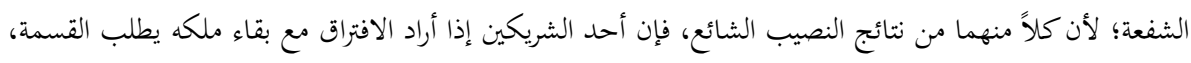

$$
\text { ومع عدمه باع، ووجب عنده الشفعة } 121 .
$$

ولم نقف على ما يمكن ذكره في مناسبة إيراد الإمام الحصيري لكتاب القسمة بعد كتاب الصلح.

والشافعية يدرجون القسمة في كتاب الأقضية والشهادات، وذلك لاحتياج القاضي إليها، ولأن القاسم كالقاضي في وجوب امتثال قسمته 122.

وبعد كتاب القسمة تناول الحصيري كتاب المواريث، وبه ختم القسم الرابع من المخظورات والمكروهات، وفي

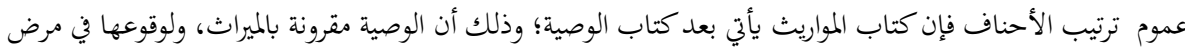

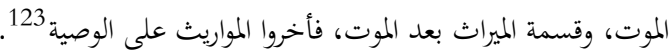

ولكن الحصيري ذكر الوصايا في قسم العبادات لما فيها من معنى للعبادة كما ذكرناه سابقا، وإيراد كتاب الميراث

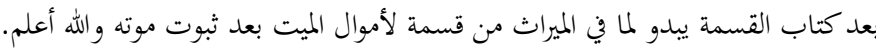

والشافعية يتناولون الفرائض تحت "كتاب بيان أحكام الفرائض والوصايا"، وأخروا كتاب الفرائض عن العبادات

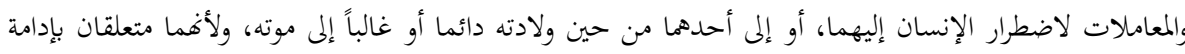

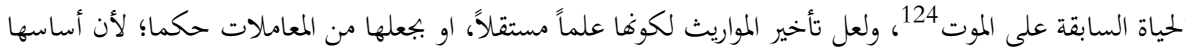

قائم على قسمة التركة، وهي تشبه المعاملات. 125

في ختام قسم الجنايات والعقوبات، نلاحظ أن الإمام الحصيري جعل الجنايات في بداية هذا القسم، وبدأ

بالجنايات لما فيها إضرار بالجسل، وربطها بما بعدها بالسرقة، لما كان في هذه الجريمة من إضرار بالمال، وبعدها تناول

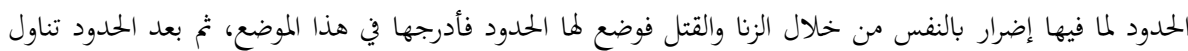
الإكراه كتاب منفصل رابطاً إياه بمعنى في ذات الإكراه حيث إن في الإكراه تمديدا بالإضرار بالنفس أو بالمال، فكان في في في

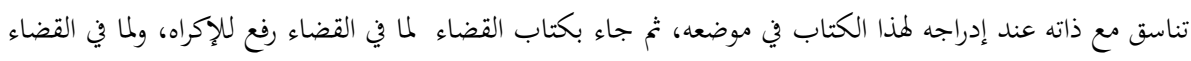
من صلاحية في الحكم في الكتب التي سبقته من جنايات وسرقة وحدود، ثم تناول كتاب الوكالة، لاعتبار الوكالة فيها معنى الشهادة عند تحصيل حقوق الله بالاستيفاء والإثبات، ولذلك ذكر بعد الوكالة كتاب الدعوى لأرتباط الدعوى عادة بالوكالة وهي أكثر ما اشتهر بالتوكيل فيه بالقضايا، ثم جاء بعدها على كتاب الإقرار لوجود علاقة الإنة بالدعاوى بمسألة

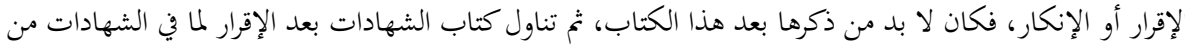
121 العيني، البناية، 122 البجري، حاشية البجري،

122 البجيرمي، حاشية البجيرمي، 403/4. 
إقرار على النفس، وجاء بعدها على كتاب الصلح لما في عدم الإقرار بالذهاب إلى الخصومة، وما تستدعيه الخصومة من

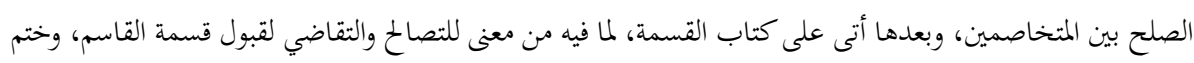

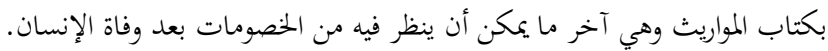
3.5. القسم الأخير.

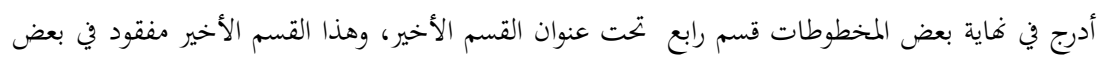

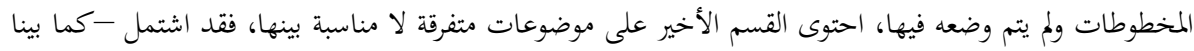

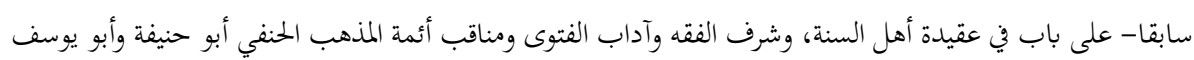
ومحمد، وباب في ذم ترك المذهب.. وغيرها. وهذه العناوين غير موجودة في كتب الفقه الشافعي. ورئ.

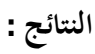

رغم أن علماء المذهب الحنفي في غالب كتبهم كانوا يميلون في تقسيمهم لأبواب الفقه على التقسيم الثلاثي

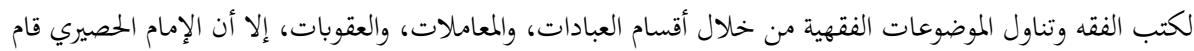

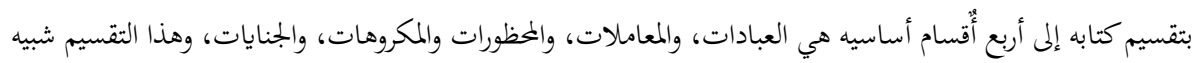
بتقسيم أبواب الفقه عند الشافعية والمالكية والحنابلة. تميز الحاوي الحصيري بفهرس لم نقف على مثيله من سبقه من العلماء حسب اطلاعنا، ورغم الاختلاف بين

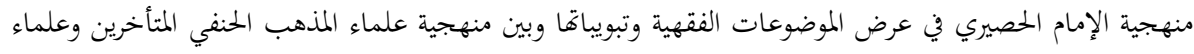

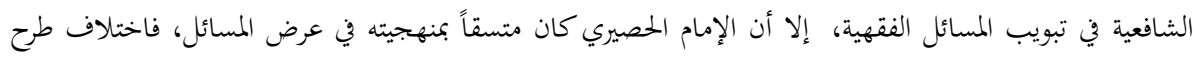

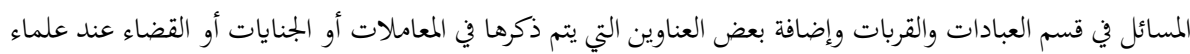
المذهب الحنفي والمذهب الشافعي، كان لتغليب معنى العبادة في الموضوع الذي تم إدراجه في باب العبادادات. ويلاحظ أن تقسيمات الإمام الحصيري لكتابه الحاوي في الفتاوى تقسيمات معتمدة على الإرتباط الموضوعي

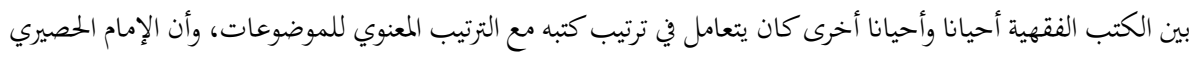

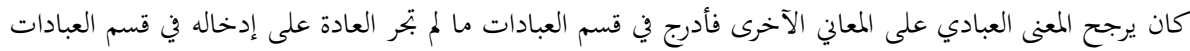
مثل النكاح والهبة والعارية.

بعد المقايسة ما بين منهجية الإمام الحصيري وعلماء المذهب الحنفي، ومقارنة منهجيتهم منهجية علماء المذهب

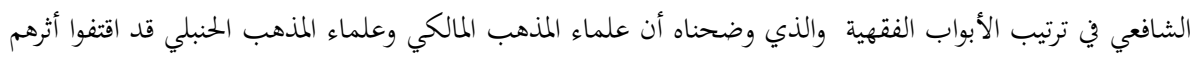

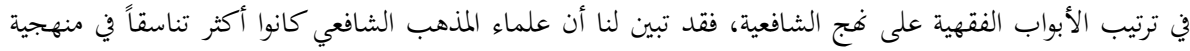

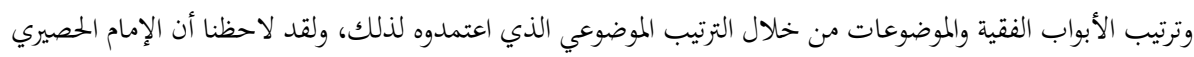

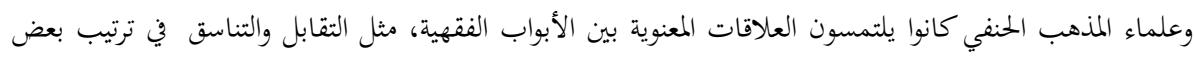

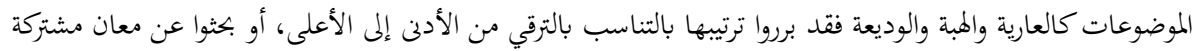

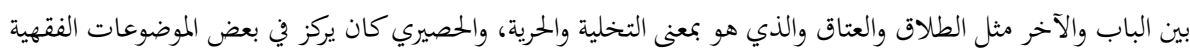

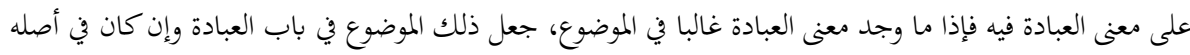




\section{Zehra ELBAKRİ \& Shaker JABARİ}

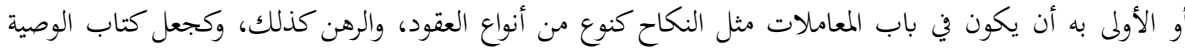

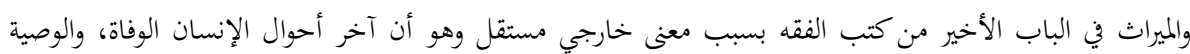
والميراث تكون في وقت الموت وبعده، وما إلى ذلك.

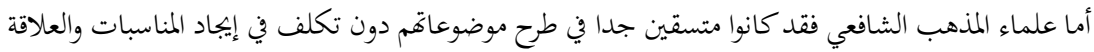

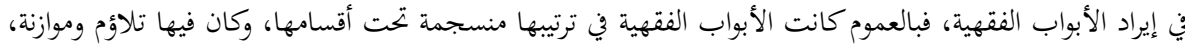

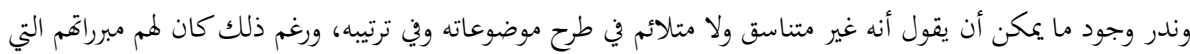

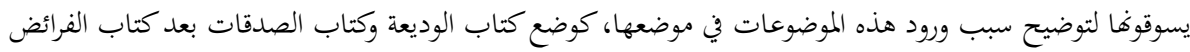

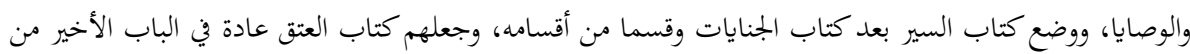

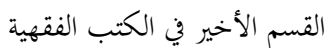

من خلال البحث قمنا بتعريف القارئ على كتاب ما زال مخطوطا في المكتبات، ولم يمقق منه إلا الشيء اليسير،

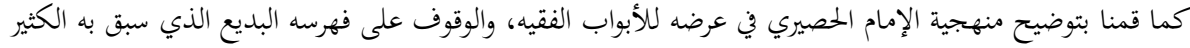

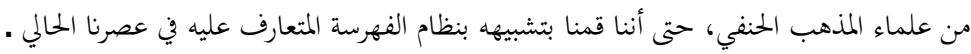
وحاولنا أن نحد أسباب إيراد الحصيري للأبواب الفقهية، والوقوف على سر ومناسبة كل باب وعلاقته بما قبله

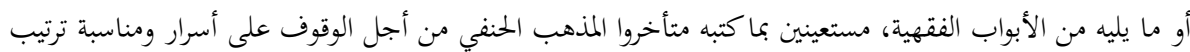

وبمقارنتنا لكتاب الحصيري في ترتيبه مع علماء المذهب المنفي، ومن ثم مع ترتيب علماء المذهب الشافعي

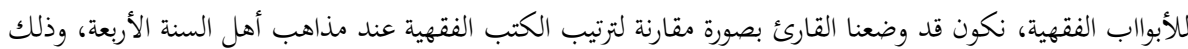

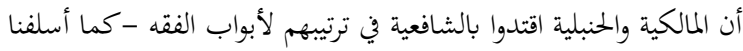

الجدول الأول: جدول ترتيب أبواب الفقه عند المالكية: مختصر خليل نموذجا.

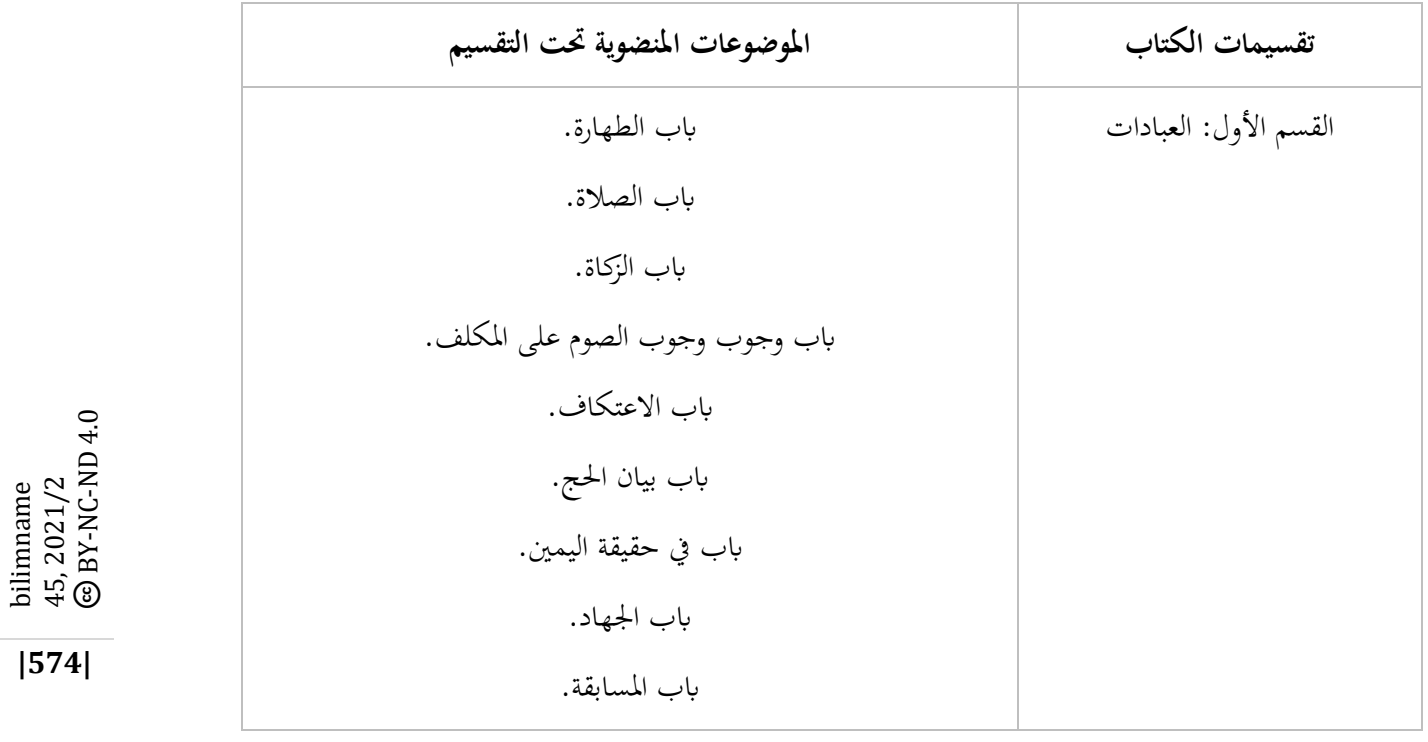


منهجية الإمام الحصيري في ترتيب الأبواب الفقهية من خلال كتابه الحاوي في الفتاوى -دراسة مقارنة

\begin{tabular}{|c|c|c|}
\hline \multicolumn{2}{|c|}{ 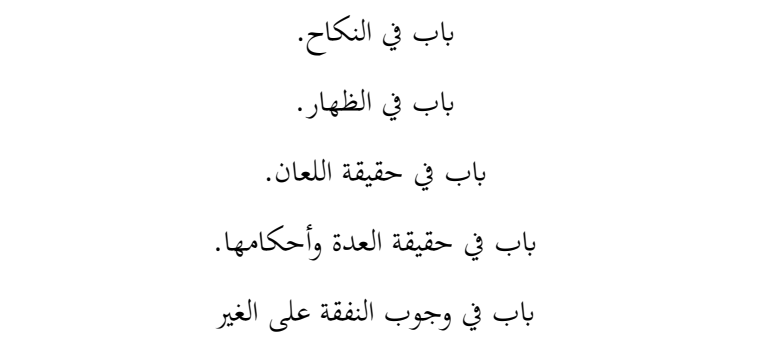 } & القسم الثاني: النكاح. \\
\hline 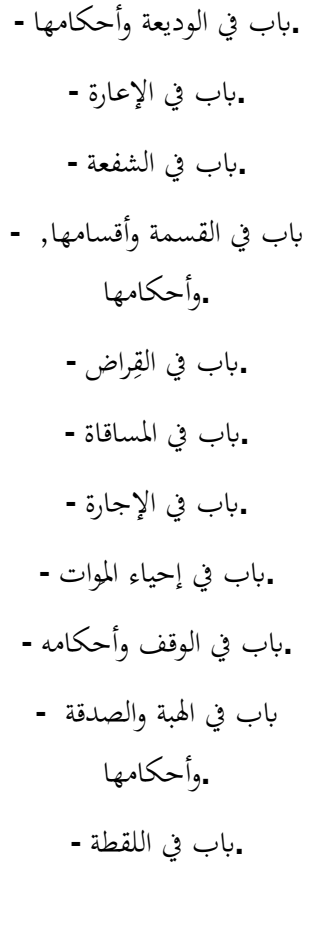 & 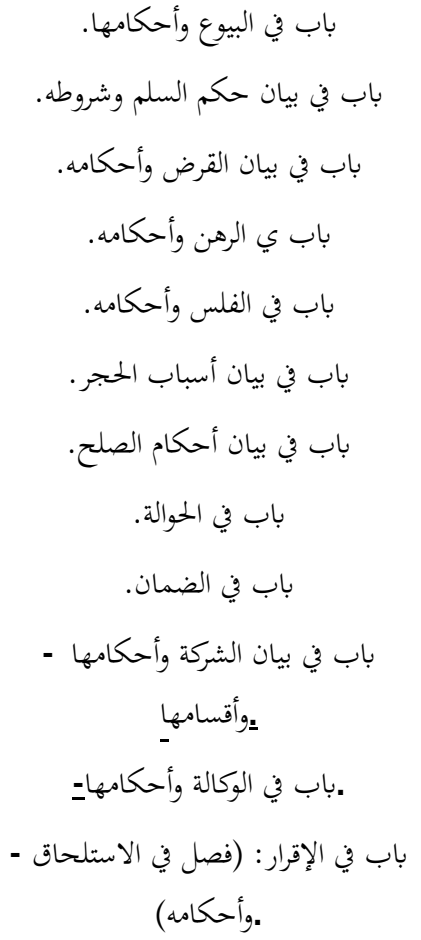 & القسم الثالث: البيوع \\
\hline & 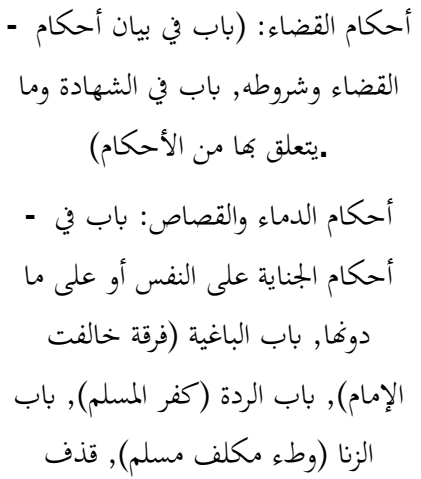 & القسم الرابع: الأقضية والجنايات \\
\hline
\end{tabular}


Zehra ELBAKRİ \& Shaker JABARİ

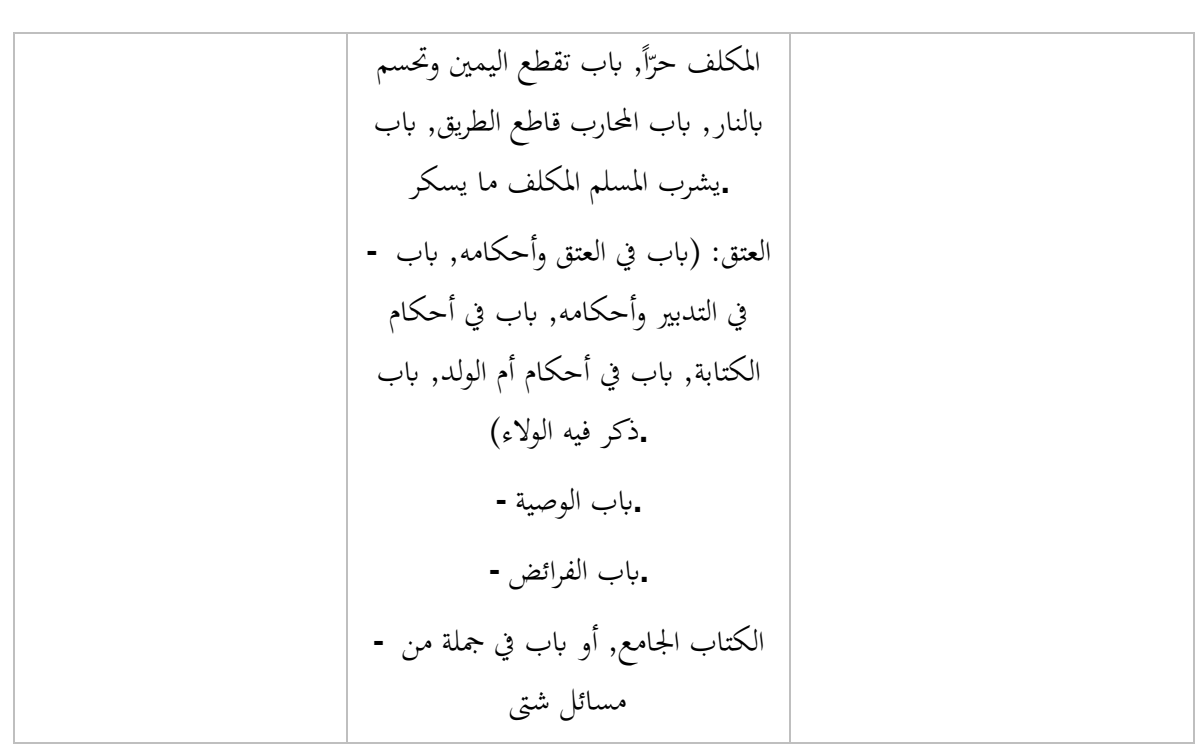

الجلدول الثاني: ترتيب الأبواب الفقهية عند (الشافعية) كتاب منهاج الطالبين نموذجاً.

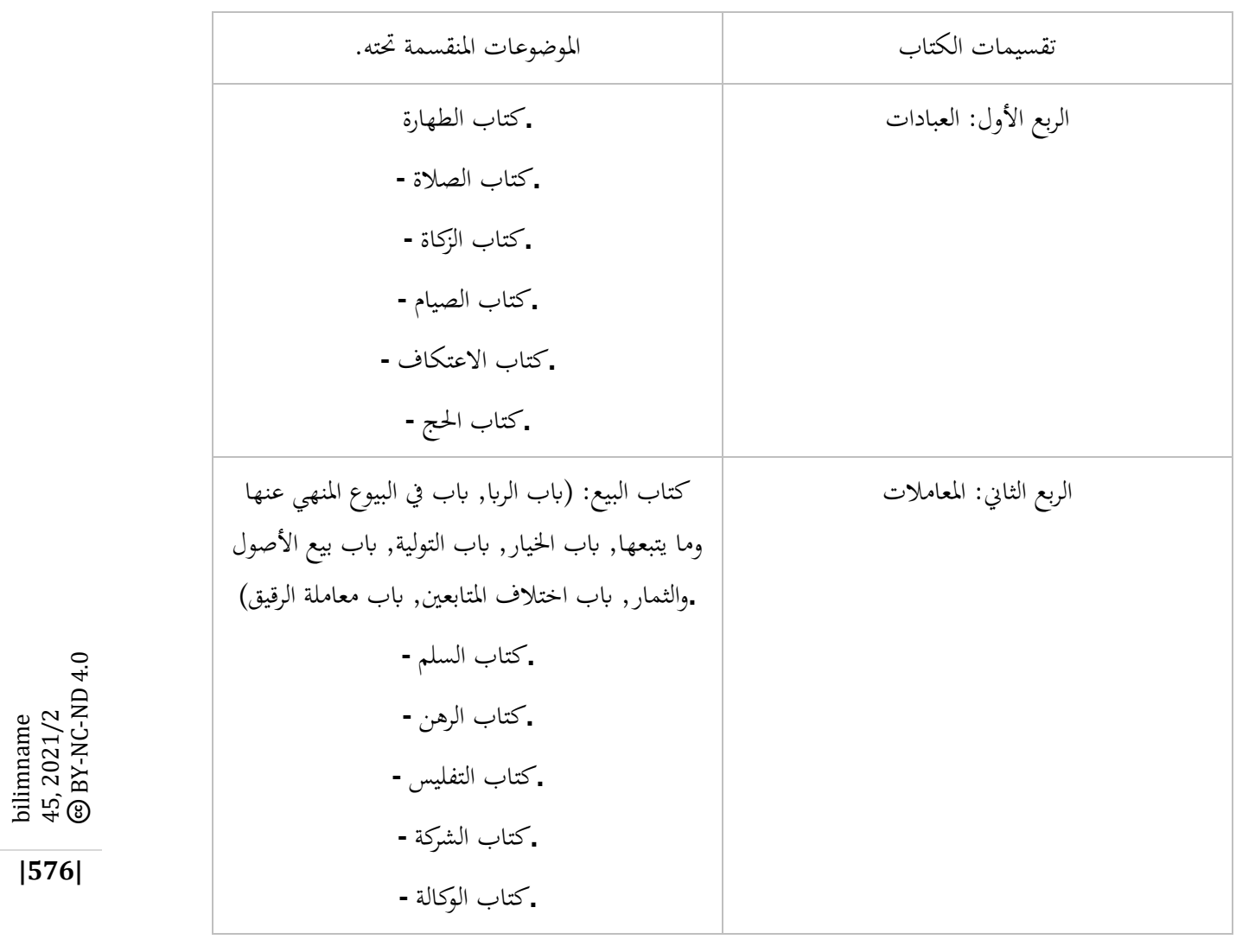


منهجية الإمام الحصيري في ترتيب الأبواب الفقهية من خلال كتابه الحاوي في الفتاوى -دراسة مقارنة

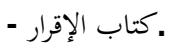

- كتاب العارية.

- كتاب الغصب .

- كتاب القِراض.

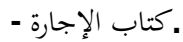

- كتاب إحياء الموات لكات

- كتاب الوقف.

كتاب الهبة - ك.

- كتاب اللقطة - كابل

- كتاب اللقيط.

- كتاب الجعالة.

- كتاب الفرائض.

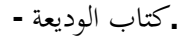

- كتاب قسم الصدقات

كتاب النكاح.

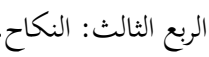

كتاب الصداق - كاق

كتاب الخلع - كابع.

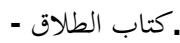

- كتاب الرجعة - مكت

.

- كتاب الظهار

- كتاب اللعان.

- كتاب العدد - كتاب

- كتاب الرضاع

- كتاب النفقات - كابع.

كتاب الديات.

الربع الرابع: الجنايات والمخاصمات

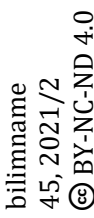

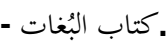


Zehra ELBAKRİ \& Shaker JABARİ

\begin{tabular}{|c|c|}
\hline 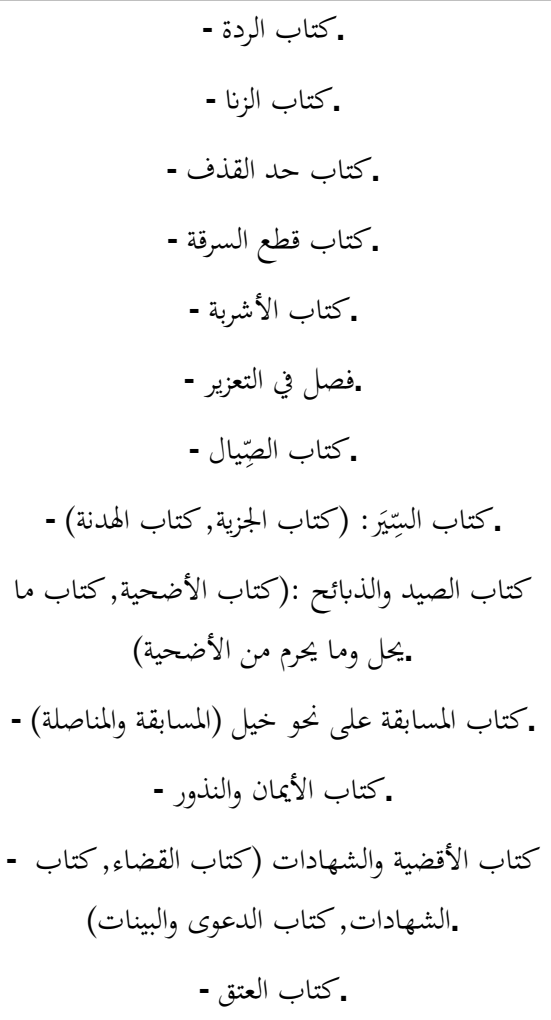 & 1 \\
\hline
\end{tabular}

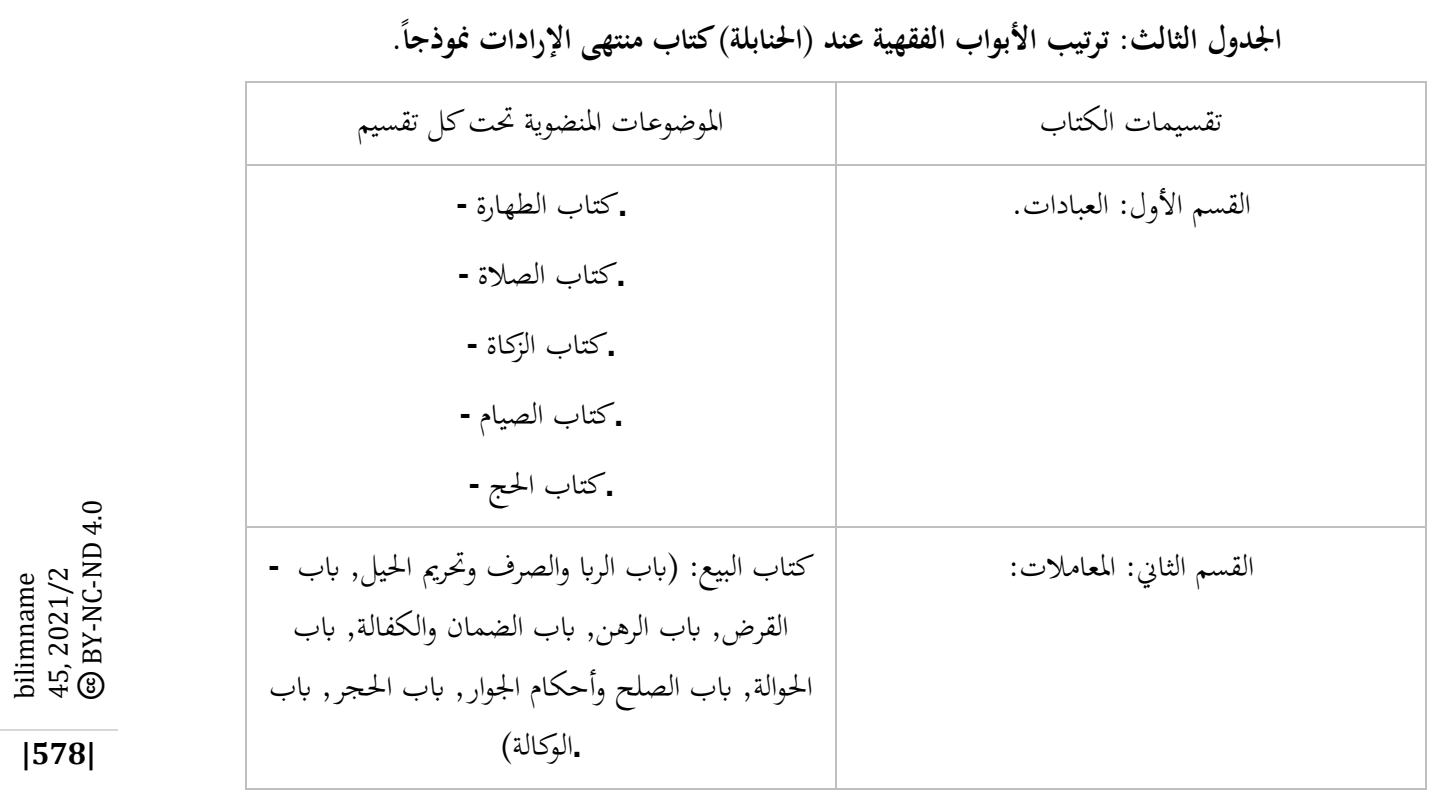


كتاب الشركة: (باب الإجارة, باب الشفعة, باب -

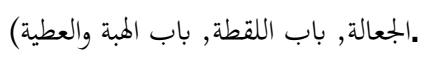

- متاب الوصايا

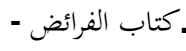

كتاب النكاح: (باب ركن النكاح وشروطه, باب القسم الثالث: كتاب المناكحات

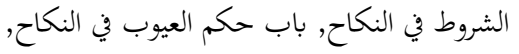

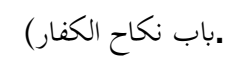

كتاب الصداق: (باب الوليمة, باب عشرة النساء) -

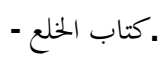

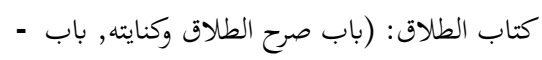

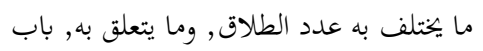
الاستثناء في الطلاق, باب الطلاق في الماضي

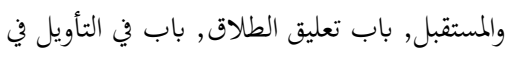
الحلف, باب الشك في الطلاق)

- كتاب الرجعة - كاب.

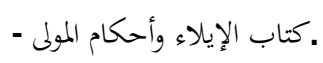

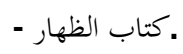

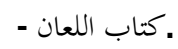

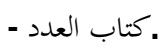

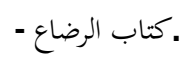

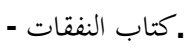

كتاب الجنايات, باب شروط القصاص, باب استيفاء

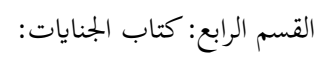

القصاص, باب العفو عن القصاص, باب ما يوجب إباب

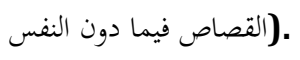

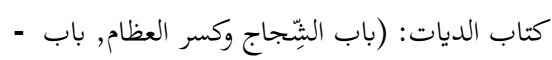

العاقلة وما تحمله, باب كفارة القتل, باب القسامة)

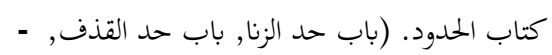

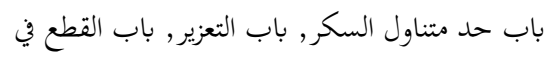

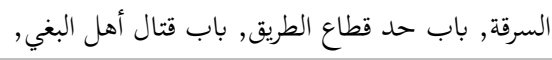


Zehra ELBAKRİ \& Shaker JABARİ

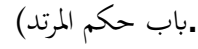

$$
\begin{aligned}
& \text { كتاب الأطعمة: (باب الذكاة) - } \\
& \text { - كتاب الصيد. } \\
& \text { - كتاب الأيمان: (باب النذر) } \\
& \text { القضاء والخصومات (كتاب القضاء والفتيا, باب آداب } \\
& \text { القاضي, باب طريق الحكم وصفته, باب حكم كتاب }
\end{aligned}
$$

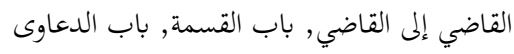

$$
\begin{aligned}
& \text { والبينات) }
\end{aligned}
$$

\section{资 战}

المصادر والمراجع

$$
\text { ملا خسرو، محمد، درر الحكام شرح غرر الأحكام، (دار إحياء الكتب العربية). }
$$

عبد الوهاب أبو سليمان، ترتيب الموضوعات الفقهية ومناسباته في المذاهب الأربعة، ط: الأولى (مكة، سلسلة بحوث

$$
\text { الدراسات الإسلامية، جامعة أم القرى، 1988). }
$$

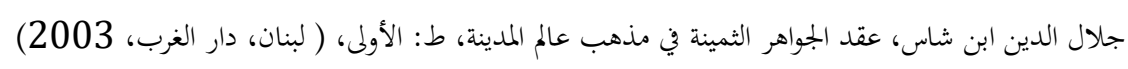

$$
\text { حققه: حميد لحمر. }
$$

الحطاب الرعيني، مواهب الجليل في شرح ختصر خليل، ط: الثالثة، (بيروت، دار الفكر، 1992). إبراهيم ابن مفلح، المبدع في شرح المقنع، ط: الأولى، (بيروت، دار الكتب العلمية، 1997). أديب الضمور ، تقسيم موضوعات الفقه وترتيبها في كتب المذاهب الفقهية الأربعة، (السعودية، بجلة العلوم الشرعية

$$
\text { واللغة العربية، جامعة سطام بن عبد العزيز) العدد: } 5 .
$$

$$
\text { عبد القادر القرشي، الجواهر المضية في طبقات الحنفية، (باكستان، مير محمد كتاب خانه). }
$$

شمس الدين الذهبي، تاريخ الإسلام ووفيات المشاهير والأعلام، ط: الأولى، تعقيق: بشار معروف، (دار الغرب

$$
\text { الإسلامي). }
$$

محمد أمين بن عابدين، رد الختار على الدر المختار المعروب بـ" حاشية ابن عابدين"، ط: الثانية، ( بيروت، دار

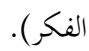


شنمس الدين الرملي، غاية المختاج إلى شرح المنهاج، ط: الأخيرة، (بيروت، دار الفكر، 1984). محمد الدميري، النجم الوهاج في شرح المنهاج، (جدة، دار المنهاج، 2004). عثمان الدمياطي، إعانة الطالبين على حل ألفاظ الفتح المعين، ط: الأولى( بيروت، دار الفكر، 1997). سليمان الجمل، فتوحات الوهاب بتوضيح شرح منهج الطلاب المعروف ب" حاشية الجمل)، (دار الفكر). فخر الدين الزيلعي، تبيين الحقائق شرحنز الدقائق وحاشية شبي، ط: الأولى، (القاهرة، المطبعة الكبرى الأميرية،

سليمان البجيرمي، حاشية البجيرمي على الخطيب، (لبنان، دار الفكر، 1995). عبد الرمن شيخي زاده، مجمع الأغر في شرح ملتقى الأبحر،(دار إحياء التراث العربي). أحمد القدوري، غختصر القدوري في الفقه الحنفي، ط:1، حققه: كامل عويضة، (دار الكتب العلمية، 1997). عبد الله البلدحي، الاختيار لتعليل المختار، (القاهرة، مطبعة الحلبي، 1937). الخطيب الشربيني، الإقناع في حل ألفاظ أبي شجاع، (لبنان، دار الفكر). محمد البابرتي، العناية شرح الهداية، (لبنان، دار الفكر). إبراهيم الشيرازي، المهذب في فقه الإمام الشافعي، ( بيروت، دار الكتب العلمية). السرخسي، المبسوط، (بيروت، دار المعرفة، 1993). كمال الدين محمد ابن الهمام، فتح القدير، (دار الفكر) علاء الدين الكاساني، بدائع الصنائع في ترتيب الشرائع، الطبعة: الثانية، ( لبنان، دار الكتب العلمية، 1986). محمد ملا خسرو، درر الحكام شرح غرر الأحكام، (دار إحياء الكتب العربية). أبو داود السجستاني، سنن أبي داود، ححقه شعيب الأرنؤوط، ط1، ( دار الرسالة، 2009). محمد الشيباني، الجامع الصغير وشرحه النافع الكبير لمن يطالع الجامع الصغير، ط1، (بيروت، عالم الكتب 1046هـ). كمال الدين ابن الهمام، فتح القدير، (بيروت، دار الفكر). محمد السمرقندي، تحفة الفقهاء،الطبعة الثانية، (لبنان، دار الكتب العلمية، 1994). زكريا الأنصاري، أسنى المطالب في شرح روض الطالب، (دار الكتاب الإسلامي). عز الدين بن عبد السلام، الغاية في اختصار النهاية، ط: الأولى، حققه: إياد الطباع، (لبنان، دار النوادر، 2016). 
Zehra ELBAKRİ \& Shaker JABARİ

olduğunu belirtmiştir. Bkz. Köse, "Hasîrî, Muhammed b. İbrâhim", TDV

İslâm Ansiklopedisi, https://islamansiklopedisi.org.tr/hasirimuhammed-b-ibrahim (12.11.2020).

Ahmet Özel, Hanefi Fıkıh Alimleri ve Diğer Mezheplerin Meşhurları, Baskı. 4., (Ankara, Türkiye Diyanet Vakfı Yayın Matbaacılık ve Ticaret işletmesi).

Orhan Ençaka. "Hanefî Fıkıh Literatüründe Gelenek Oluşturan Kayıp Bir Metin: Muhtasarü'l-Kerhî”. İslâm Araştırmaları Dergis, sayı: 37, (2017).

Arif Atalay, İslam Hukukunda Teslim Tesellüm (Kabz) (Kayseri: Kimlik Yayınları, 2016), 109

Bilal Aybakan, "Fürû' Fıkıh Sistematiği Üzerine", Marmara Üniversitesi İlâhiyat Fakültesi Dergisi 31 (2006/2).

Yıldız Demir-Ahmet M. Peșe, "İslâm Hukuk Sistematiği ve Literatürü", İslâm Hukuku El Kitabı (Ankara: Grafiker Yayınları, 2015).

Bekir KARADAĞ, İslâm Hukuku Sistematiğine Dair Bir İnceleme (Kitâbu'nNikâh Örneği), (Harran, Harran Üniversitesi İlahiyat Fakültesi Dergisi, sayı:43).

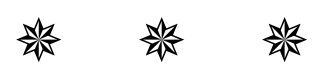




\title{
İMAM EL-HASîRî'(500/1107)'İN EL-HAVÎ FÍL- FETÂVÂ ADLI ESERININN FIKH BABLARININ SISTEMATIĞİ: KARȘILAȘTIRMALI BIR ÇALIŞMA
}

\author{
Zehra ELBAKRIंa
}

Shaker JABARI ${ }^{b}$

\section{Geniş Öz}

Çalışmada Hanefi mezhebi klasik eserlerini dikkate alarak İmam Hasirînnin fıkıh bablarını taksimatından ve konuları ele alma metodundan bahsedilmiştir. Daha sonra fıkıh konularının Şafii mezhebindeki taskimatına ve neye göre taksim edildiklerini zikretmeye çalıştık.

Giriş bölümünde genel olarak Hanefi alimleri, özel olarak da Hasirînin eseri ile Şafii mezhebindeki eserlerini mukayese ettik. Zira bu mukayese dört mezhebi mukayese etmek demektir. Şafii mezhebi alimlerinin Maliki ve Hanefi alimlerine etkisinden bahsettik.

Çalışmanın ilk bölümünde Hasirînin eserinin içindekiler kısmından bahsedilmiştir.

Birinci bölümde Hasirînnin ibadat konusunu ele alarak dört mezhebin eserlerine mutabık kaldığını izah ettik. Ancak ne varki ibadat bölümünde ele aldığı bölümler diğer mezheplerden farklılık arz etmektedir.

Hasirî ibadat bölümünde diğer alimler gibi oruç namaz ve zekat bablarını ele almıştır. Ancak zekat babından hemen sonra evkaf, 'itak, udhiye bablarına yer vermiştir. Hasirî, hanefi mezhebindeki diğer alimlerinin muamelat bölümünde ele aldığı bu konuları, ibadat bölümünde zikretmesinin sebebini, ibadet manasının bu üç başlıkta mündemiç olduğu şeklinde izah etmektedir. Vakıf konusu şafii mezhebinin bazı eserlerinde bey’ kitabında geçmektedir. Bunun gerekçesinin de bu konuların her birinde zevalü'l mülk (malın kaybı)

a Dr., Sakarya Üniversitesi, zahra.albakri7@gmail.com

b Dr., Sakarya Üniversitesi, std_shaker@hotmail.com 
manasının olduğunu söylemektedirler. Ancak yine şafii mezhebinin diğer bazı eserlerinde ise bu konular ihyaü'l emvat bölümünden sonra zikredilmiştir. Bunun gerekçesini ise bu konuların ihdasü’l mülk ifade ettiği şeklinde açıklamışlardır.

Daha sonra Hasirî hem ibadet hem ticaret manası taşıyan nikah babını, ibadet ile alakasından dolayı bu bölümde zikretmeyi uygun görmüştür. Oysa Hanefi mezhebinde bu konu muamelat bölümünün ilk konusudur. Şafiiler ise bu konuyu ayrı bir bölüm olarak zikretmiş ve konuya tealluk eden her konuyu (mehir, nafaka, boşanma vb.) bu bölümde zikretmişdir

Hasirî nikah bahsinden sonra cihad babını ele almıștır, bu da nikah ve cihadın her ikisinin Müslümanın varlığının temel nedeni olarak görmesinden kaynaklanmaktadır. Şafii mezhebi alimleri ise cihad konusunu cezalar bahsinde ele almıştır.

Daha sonra Hasirî ibadet bölümünde 'itak babını ele almıștır. Şafiiler ise bu konuyu itakü'n nar, cehennem ateşinden men edilmek ümidiyle son bölüm olarak ele almışlardır. Hasirî bu bölümde hac ibadetiyle bağlantılı olduğu için kurban konusunu da ele almıștır. Şafii mezhebinde ise kurban konusunun nereye dahil olacağı hakkında farklı görüşler vardır. Kimisi zebaih kimisi hudut bölümleri altında ele almıştır.

Sonra uhdiyye babından bahseder çünkü bunda da ibadet manası vadır. Şafii ise lukatadan sonra daman konusunu ele alır çünkü her ikisinde de dürüstlük hakimdir. Hasirî daha sonra ibadetler bölümünde bağıș ve ariyet babını ele alır. Şafii ise ikrardan sonra ariyeti ele alır ve vakfın hemen ardından da bağış babını zikreder.

Hasirî ibadet bölümünde lukatadan bahseder ve bunun sebebi de Allah'ın haklarından biri olup farz mesabesinde olmasıdır. Şafiiler ise bağışlardan sonra lukatayı ele aldılar. Ve Hasirî bu bölümü vasiyet babıyla bitirdi, Allah tarafından bir emir olduğu için.

Şafiiye gelince onlar vasiyyeti farzlardan sonra zikrederler. Muamelat bölümüne gelince Hasirî burada ilk olarak buyu' bölümünü zikreder. Çünkü ibadetlerden bahsettikten sonra Allah'ın haklarından biriyle başlamış ve böylece de Şafii kitaplarındaki metodu takip etmiştir.

Buyu' babından sonra şufa babı gelmektedir çünkü konular birbiriyle bağlantılıdır.

Şafii, şufa konusunu gasp konusundan sonra ele alarak Hanefi mezhebini takip etmiştir. Sonra Hasirî şufa ve buyu' ile bağlantılı olduğu için icara |584| konusunu ele almıștır. Şafii alimleri ise icara'dan önce şufadan bahseder ve 
icara'dan sonra juala babını ele alırlar. Bundan sonra Şafii şerike'den bahseder. Hanefiler ise şerike'yi mefkud babından sonra ele alırlar. Hasirî şerike'den sonra ortakçılık babını ele alır, Şafii ise ortakçılığı juala babından sonra ele alır. Hasirî daha sonra mudarebe babını zikreder ki bu da bir şerike'dir. Şafii mezhebi alimleri ön alım ve mevduattan sonra gelen el-kirad (borç veren) başlığı altında ele almıştır.

Hasirîinin eserinde muamelat bölümün rehin babıyla sonlandırır. Daha sonra üçüncü bölüm olan el-mahzurat ve ve'l mekruhat bölümüne geçer. Bu bölümde hanefi alimleri yapılmasını kerih gördükleri şeyleri ele alırlar ve ilk olarak boşanma konusunu zikrederler. Şafii alimleri ise nikah bölümünde hula' dan sonra boşanma konusunu ele alırlar.

Daha sonra gasp veya zorlama babı gelir ve bunlar haram olduğu için yasaklar bölümünde ele almıştır. Şafiiler ise bu konuları ariyet babında ele almışlardır. Daha sonra bu bölümü de kefalet babıyla bitirir. Şafii alimleri havale'den sonra daman konusunu ele almıştır.

Hasirî dördüncü bölüme ise rehin konusuna en yakın konu olduğu için cinayat babıyla başlamıştır. Şafiide ise cinayat nikah bölümünden sonra ayrı bir bölümdür. Hasirî bu bölümü daha sonra hırsızlık, ondan sonra hudut, sonra da ikrah ve ikrar, sonra da şehadet, sulh ve bu bölümü son olarak da miras konusunu ele alarak tamamlamıștır.

Son olarak bir Hâtime ele aldıeserde müellif tarafından "hâtime" adı verilen bir kısım daha yer almakta olup bu bölüm şu başlıkları taşıyan 8 fasıldan oluşmaktadır: 1) Selef-i Salihinin itikadını, siyerleri, bidatlerin şerhi ve bidatlere karşı nasıl muamele edileceğinin beyânı, 2) Fetva konusunda ihtiyatlı davranmak, 3) Fıkhın Şerefi, 4) Ebu Hanife'nin menkıbeleri, 5) Mezhebini terk eden kişinin zemmedilmesi, 6) Ebu Yusuf'un menkıbeleri, 7) Muhammed b. Hasen el-Șeybanî'nin menkıbeleri, 8) Fakihlere davranma şekli.

Anahtar Kelimeler: Mushaf-ı Șerif, Mekkî hattı, Vahiy Kâtibi, Medenî hattı, İbnü'n-Nedîm. 


\section{METHODOLOGY OF IMAM AL-HUSAYRI IN STRUCTURING THE FIQH TOPICS IN HIS BOOK, AL-HAWI FIL FATAWA: A COMPARATIVE STUDY}

Zehra ELBAKRİa

\author{
Shaker JABARI ${ }^{b}$
}

\section{Extended Abstract}

In our study here we talked about Imam Hosary's division of the Islamic laws or and we tried to understand Imam-Hosary's presentation formats of the topics by going back through the Hanafi schools' books and look for the machinery of mentioning and presenting of topics and division of the Islamic laws in their books.

After that we approach the division of the Islamic laws for "Al-Shafiya "and why they mentioned ways and directions of how to present the jurisprudence laws.

In the introduction we mentioned why we compared the Imam Hosary and the Hanafi schools' divisions of The Islamic laws with Shafiya scientists' division and we explained how the Malikiya and hanabla scientists were effected by the shafiya's divisions while writing their divisions of The Islamic laws in their books, and us comparing the hanafy and Hosary's divisions with the shafiya's divisions is like comparing the Islamic laws' divisions of the four "Mathahb" or the four schools.

In the first part of the research we talked about the Hosary's book's catalogue and we presented the catalogue's content which was written at the beginning of Al-Hawy-Al-Hosary's manuscripts. After that in the third part we analyzed the doctrinal substantive arrangements for the Imam-Al-Hosary, and we explained that Imam-Al-Hosary agreed with the four schools or the four

\footnotetext{
a Ph.D., Sakarya University, zahra.albakri7@gmail.com

b PhD., Sakarya University, std_shaker@hotmail.com
} 
Mathahb on putting the worships part in the first branch and we explained their justification and reasoning for this agreement, but Even though AlImam-Al-Hosary agreed on that he still included some books in the worships branch that the other scientists didn't include. Al-Imam-Al-Hosary put the fasting, prayer, and zakat book symmetric with the other four schools' scientists, directly after the zakat he put the book of Waqef, Odhiya (sacrifice), And Ataq, even though the Hanifa scientists put the waqaf after the Sherk (polytheism) book which is in the transactions branch, and we explained that the reasoning for that according to Al-Imam-Al-Hosary is that the meaning of worshiping is found in these three things or these three topics. Some of the Shafiya put the "Wakaf "after the

"Bayi "book because there is a meaning for Zawal-Al-Mlk in each one of them. And some of them put it after the book of bringing back the dead which is called Ehyaa-Al-Amwat and that's because bringing back the dead to life is considered Zawal-Al-Mlk unlike the Wakaf which is Ehdath-Al-Mlk which is the opposite of Zawal-Al-Mlk.

And then after that the Hosary Imam mentions the Nikokh book in the worships branch, and we explained that the Hosary talked about the nikokh book during the worships branch because in someway it's considered worshiping and in another way it's considered a transaction but it's presented as worshiping and not as a transaction.

While The Ahnaf put the nikokh in the first book of the transactions branch, and The Shafiya put it in a quarter separately alone and underneath it they put everything that has to do with nikokh whether it's dowry, alimony, divorce, depose etc...

And after nikokh, The Hosary mentions the book of Sayr, and the reason for that is because nikokh and the jihad (battle) are reasons for the Islam and Muslim's existence, and The Shafiya include it in the quarter of crimes.

After that The Hosary talks about the book of Ataq, as it has a meaning for worshiping. The Shafiya include the Ataq book during their last Fiqh books in hopes to be prohibited from hell fire.

And after that The Hosary mentions the Odhiya or the sacrifice and that's Because it's attached and paired with pilgrimage. The Shafiya put the Sacrifice in the book of carcasses, they disagreed on where to put it, some of them wrote it during the last quarter of the worships branch and some of them wrote it in the book of limitations. Then he talks about the book of deposit, it has a meaning of worshiping. The Shafiya include the deposits after The Luqatah because they both have a meaning for honesty. The Hosary 
then talkes about the book of donations and the book of nude during the worships branch. The Shafiya include the nudity book after the book of disclosure and put donations during the transitions branch right after the Waqaf. In the branch of worships, The Hosary talks about luqatah and that's because it's a right from god's rights and it might be obligatory. For Shafiya they put luqatah after donations. Then end Hosary the branch of worships with commandments (or wills) and maybe a reason for that is that commandments are obligatory and some scientists say it's a must. As for The Shafiya they put the commandments right after the obligations. Started the Hosary Imam the transactions branch with the sales book, because after mentioning worships which are one of God's right. He started with the transactions which are worshiping's right and he similarly followed what The Shafiya followed in their books.

And after the sales book comes the Shufa book because thy are connected together.

The Shafiya followed the Hanifa schools by putting the shufa after usurper. Then the Hosary talked about the book of rents because it's connected to shufa and sales. And The Shafiya mention the shufa before rents and after rents they put the book about rules of rewards (juala). After that The Shafiya Imam mentions Al-Shareeka (rules of partnership), usually for The Ahnaf Shareeka comes after The Book of Mafqood". "After that The Hosary talks about the book of sharecropping which is a type of Shareeka, The Shafiya put sharecropping after jaala. After that he talks about the book of mudaraba (investment)and it's a type of Shareeka, The shafiya put it under the title of Al-Qarad (loaner) after preemptions or after deposits.

The Hosary ends the transactions branch with the book of "Raham" and the reason for why it's included in this branch is because it has its terms and conditions. Then he starts with the third branch, Forbidden and hated in divorce. In this branch the Shafiiy mentions the things he hates doing, that's why he started with divorce. The Shafiya mention divorce during the quarter of nikokh after Khula.

After that comes the book of usurpation or (forcing), because it's haram to do it, he put it with the forbiddens branch. The Shafiya put it after the book of Aarya (nude) because both of them must get acceptance. He then ends this branch with the book of guarantees, it's clear why it's mentioned after usurpation (Ghasib). The Shafiya include guarantees after Hwala (rules of transference of debts) and in the fourth branch: book of "Jinayat", The Hosary started with the book of jinayat, it's connected with the book of mortgage, 
mortgage is connected to money and jinayat is connected to self profit. For Shafiya, jinayat comes after the quarter of nikokh. After that he talks about the book of Robbing or stealing, then book of limits, then the book of hatred, then the book of Qadaa, then the book for rules of agency, then the book of daawa, then the book for rules of admission, then the book of Shahadaat (witnesses), then the book of sulh (rules for settlement). The the Hosary ends the fourth branch with the book of inheritance.

Keywords: Al-Husayri, Jurisprudential Tab, Al-Hawi. Jurisprudence topics.

$$
\text { 淡淡 }
$$

